\title{
Synaptic Properties of SOM- and CCK-Expressing Cells in Dentate Gyrus Interneuron Networks
}

\author{
Shakuntala Savanthrapadian, ${ }^{1}$ Thomas Meyer, ${ }^{1}$ Claudio Elgueta, ${ }^{1}$ Sam A. Booker, ${ }^{2}$ Imre Vida, ${ }^{2}$ and Marlene Bartos ${ }^{1}$ \\ ${ }^{1}$ Physiologisches Institut I, Systemic and Cellular Neuroscience, Albert-Ludwigs-Universität Freiburg, 79104 Freiburg, Germany, and ${ }^{2}$ Institute for \\ Integrative Neuroanatomy and NeuroCure Cluster, Charité Berlin, 10115 Berlin, Germany
}

\begin{abstract}
Hippocampal GABAergic cells are highly heterogeneous, but the functional significance of this diversity is not fully understood. By using paired recordings of synaptically connected interneurons in slice preparations of the rat and mouse dentate gyrus (DG), we show that morphologically identified interneurons form complex neuronal networks. Synaptic inhibitory interactions exist between cholecystokinin (CCK)-expressing hilar commissural associational path (HICAP) cells and among somatostatin (SOM)-containing hilar perforant path-associated (HIPP) interneurons. Moreover, both interneuron types inhibit parvalbumin (PV)-expressing perisomatic inhibitory basket cells (BCs), whereas BCs and HICAPs rarely target HIPP cells. HICAP and HIPP cells produce slow, weak, and unreliable inhibition onto postsynaptic interneurons. The time course of inhibitory signaling is defined by the identity of the presynaptic and postsynaptic cell. It is the slowest for HIPP-HIPP, intermediately slow for HICAP-HICAP, but fast for BC-BC synapses. GABA release at interneuroninterneuron synapses also shows cell type-specific short-term dynamics, ranging from multiple-pulse facilitation at HICAP-HICAP, biphasic modulation at HIPP-HIPP to depression at BC-BC synapses. Although dendritic inhibition at HICAP-BC and HIPP-BC synapses appears weak and slow, channelrhodopsin 2-mediated excitation of SOM terminals demonstrates that they effectively control the activity of target interneurons. They markedly reduce the discharge probability but sharpen the temporal precision of action potential generation. Thus, dendritic inhibition seems to play an important role in determining the activity pattern of GABAergic interneuron populations and thereby the flow of information through the DG circuitry.
\end{abstract}

Key words: cholecystokinin; dentate gyrus; GABA; interneuron; somatostatin; synaptic transmission

\section{Introduction}

The dentate gyrus (DG) acts as interface between the entorhinal cortex and the hippocampus (Andersen et al., 1971). Its computational function involves the translation of multimodal patterns from the neocortex into sparse codes for the CA3 area (Treves and Rolls, 1994; Leutgeb et al., 2007; McHugh et al., 2007). Consistent with this theory, population activity in the DG is tightly controlled by powerful GABA-mediated synaptic inhibition (Nitz and McNaughton, 2004). GABAergic cells are characterized by a high diversity with respect to their morphological, physiological, and neurochemical characteristics and target cell specificity (Freund and Buzsáki, 1996; Somogyi and Klausberger, 2005;

\footnotetext{
Received Dec. 30, 2013; revised May 2, 2014; accepted May 7, 2014.

Author contributions: M.B. designed research;S.S., T.M., C.E., S.A.B., I.V., and M.B. performed research;S.S., T.M., C.E., S.A.B., and M.B. analyzed data; I.V. and M.B. wrote the paper.

This work was supported by the Schram-Foundation (M.B.), Lichtenberg Professorship Award (VW-Foundation; M.B.), the Deutsche Forschungsgemeinschaft (BA1582/2-1; M.B.), Excellence Initiative "Brain Links Brain Tools" (M.B.), FRIAS (M.B.), the MOTI-VATE MD-Program of the Medical Faculty, University of Freiburg (Else KrönerFresenius Foundation; T.M.), and the Excellence Initiative of the German Research Foundation (DFG EXC 257, I.V.). We thank Dr. A. Kulik for support in high-magnification light microscopy; Dr. Peer Wulff and Dr. Laura Ansel for providing rAAV-FLIP-ChR2-tdT; D. Curtis (Novartis, Cambridge, MA) for the fast evaluation of our manuscript; and Karin Winterhalter and Kerstin Semmler for technical assistance.

The authors declare no competing financial interests.

Correspondence should be addressed to Dr. Marlene Bartos, Physiologisches Institut I, Systemic and Cellular Neuroscience, Albert-Ludwigs-Universität Freiburg, Hermann-Herder-Straße 7, 79104 Freiburg, Germany. E-mail: marlene.bartos@physiologie.uni-freiburg.de.

DOI:10.1523/JNEUROSCI.5433-13.2014

Copyright $\odot 2014$ the authors $\quad 0270-6474 / 14 / 348197-13 \$ 15.00 / 0$
}

Hosp et al., 2013). In particular, the identity of their subcellular targets and the functional and dynamic properties of their output synapses are important determinants of their computational role in cortical networks. Moreover, diversity of synaptic inhibition may be essential for neuronal circuits to perform complex operations (McBain and Fisahn, 2001; Isaacson and Scanziani, 2011; Xu et al., 2013).

Depending on synapse output location along the somatodendritic axis of principal cells, interneurons have been broadly classified into perisomatic and dendritic inhibitory cells (Freund and Buzsáki, 1996). The functional properties of perisomatic inhibitory synapses of parvalbumin (PV)-expressing basket cells (BCs) and axo-axonic (AA) cells are well described in the hippocampus and DG. Transmission at these synapses is characterized by a fast time course and large conductance (Bartos et al., 2002, 2007; Glickfeld and Scanziani, 2006) allowing precise control of timing and probability of spike generation in target cells (Pouille and Scanziani, 2001). These characteristics critically contribute to the synchronization of principal cell assemblies and the generation of fast network oscillations (Cobb et al., 1995; Csicsvari et al., 2003; Buzsáki and Draguhn, 2004; Tukker et al., 2007; Doischer et al., 2008; Klausberger and Somogyi, 2008). Dendritic inhibitory synapses are proposed to control electrogenesis, synaptic plasticity, and activity states in their targets (Miles et al., 1996; Leão et al., 2012; Chiu et al., 2013; Xu et al., 2013). Light- and electronmicroscopic studies indicate that the majority of GABAergic syn- 
apses are distributed along the entire dendritic axis of principal cells and interneurons (Halasy and Somogyi, 1993; Han et al., 1993; Gulyás et al., 1999; Megías et al., 2001), indicating that interneuron activity, and thus feedforward and feedback inhibition may, in turn, be under dendritic inhibitory control. However, little is known about properties of inhibitory signaling mediated by different types of GABAergic cells targeting interneurons, their precise synapse location, and their impact on interneuron activity.

Here we addressed this question by performing paired wholecell recordings of synaptically connected interneurons in the rodent DG. We focused on two major morphologically and neurochemically identified interneuron types: (1) CCK-positive $\left(\mathrm{CCK}^{+}\right)$hilar commissural associational path (HICAP) cells with axon collaterals largely located in the inner molecular layer, which contains fibers from the commissural-associational (CA)path, thus transmits inputs from the ipsilateral and contralateral hippocampus and (2) SOM-positive $\left(\mathrm{SOM}^{+}\right)$hilar perforant path associated (HIPP) cells with axon arborizations in the outer molecular layer coaligned with the perforant-path (PP) from the entorhinal cortex (Halasy and Somogyi, 1993; Han et al., 1993; Buckmaster and Schwartzkroin, 1995; Mott et al., 1997).

\section{Materials and Methods}

Electrophysiology. Transverse hippocampal slices (300-350 $\mu \mathrm{m})$ were cut with a VT 1200 S vibratome (Leica) from 18- to 24-day-old Wistar rats, transgenic mice expressing enhanced green fluorescent protein (eGFP) in $\mathrm{SOM}^{+}$inhibitory interneurons (GIN mice) (Oliva et al., 2000) or SOM-Cre mice (C-SST ${ }^{\mathrm{tm} 1 \mathrm{Npa}}$ generated by H. van der Putten; Novartis Pharma; MTD 36044, and rederived using embryos kindly provided by $\mathrm{P}$. Jonas, IST Austria). Som-Cre knock-in mice were generated by targeting NLS-Cre into the endogenous mouse SOM gene of BALB/c embryonic stem cells (Dinkel et al., 1999), which were used to produce chimeric male mice and heterozygous progeny carrying the modified somatostatin (SST) gene, hereafter referred to as SOM-Cre mice. Mutant offspring were identified by PCR using the following oligonucleotides: primer 1 (0042; CTAGGCCACAGAATTGAAAGATCT) and primer 2 (0043; GTAGGTGGAAATTCTAGCATCATCC), corresponding to the $5^{\prime}$ terminus of the SST-Cre gene (eurofins, mwg/operon). Mice heterozygous for the SST-Cre gene were used in this study. All animal procedures were performed in accordance to national and institutional legislations (license no. G-11/53; X-12/20D).

Acute hippocampal slices were superfused with an artificial CSF (ACSF) consisting of (in mM) NaCl 125, $\mathrm{NaHCO}_{3} 25, \mathrm{KCl} 2.5, \mathrm{NaH}_{2} \mathrm{PO}_{4}$ 1.25, D-glucose $25, \mathrm{CaCl}_{2} 2$, and $\mathrm{MgCl}_{2} 1$ (equillibrated with $95 \% \mathrm{O}_{2} / 5 \%$ $\mathrm{CO}_{2}$ ) for $20-30 \min \left(34^{\circ} \mathrm{C}\right)$ and then stored at room temperature. Recording pipettes (wall thickness: $0.5 \mathrm{~mm}$; inner diameter: $1 \mathrm{~mm}$ ) were pulled from borosilicate glass tubing (Flaming-Brown P-97 puller, Sutter Instruments) and filled with a solution containing (in $\mathrm{mM}$ ) K-gluconate $110, \mathrm{KCl} 40$, HEPES 10, $\mathrm{MgCl}_{2} 2, \mathrm{Na}_{2}$ ATP 2, EGTA 0.1 , and $0.2 \%$ biocytin (Invitrogen) ( $\mathrm{pH} 7.2 ; 290-310 \mathrm{mOsm})$. The final pipette resistance was $2.5-5 \mathrm{~m} \Omega$. During paired whole-cell patch-clamp recordings of synaptically connected interneurons, single-action potentials were evoked by brief depolarizing current injection in the presynaptic interneuron (1-2 ms, 400-1000 pA), and uIPSCs were recorded ( $-70 \mathrm{mV}$ holding potential) in the postsynaptic cell (recording temperature: $31^{\circ} \mathrm{C}-32^{\circ} \mathrm{C}$ ). GFP-expressing interneurons were identified during the experiment using epifluorescence illumination. Recordings were obtained from neurons in the DG under visual control using infrared differential interference contrast video microscopy (Sauer and Bartos, 2010). Paired recordings were performed in the presence of $2 \mathrm{~mm}$ kynurenic acid (Sigma-Aldrich) in the extracellular bath solution to block EPSCs. In 2 HICAP-HICAP and 2 HIPP-HIPP pairs, $10 \mu \mathrm{M}$ SR95531 (Tocris Bioscience) was bath-applied at the end of the paired recording to confirm that uIPSCs were mediated by $\mathrm{GABA}_{\mathrm{A}}$ receptors. Recordings were performed with a Multiclamp 700B or an Axopatch 200B amplifier (Molecular Devices). Series resistance (15-20 $\mathrm{M} \Omega$ ) was compensated in voltage-clamp at $75 \%-85 \%(20-40 \mu$ s time lag) and in current-clamp at 100\% (5-10 $\mu$ s time lag) during paired recordings but not compensated during optophysiological experiments. Signals were filtered at $5-10 \mathrm{kHz}$ and digitized at $20-40 \mathrm{kHz}$ with a Power 1401 laboratory interface (Cambridge Electronic Design). Stimulus-generation and data acquisition were performed with a custom-made Igor-based program (FPulse, courtesy of U. Fröbe, University of Freiburg, Freiburg, Germany).

Optophysiology. For cell type- and brain area-specific excitation of interneurons by channelrhodopsin 2 (ChR2), we performed stereotaxic injections of recombinant adeno-associated viruses (rAAVs) bilaterally into the ventral DG of SOM-Cre recombinase-expressing mice (P20P90; $4 \mu \mathrm{l}$ of the rAAV). The expression cassette of rAAVs contained tdTomato (tdT) and ChR2 between inverted incompatible two tandem loxP sites (rAAV-FLIP-ChR2-tdT; courtesy of P. Wulff, University of Kiel, Kiel, Germany). Mice were anesthetized with 3\% isoflurane (in $100 \% \mathrm{O}_{2}$ ) by inhalation, fixed in a stereotaxic frame; anesthesia was maintained on $1.5-2 \%$ isoflurane throughout the surgery. Small holes $(\sim 1 \mathrm{~mm}$ diameter $)$ were drilled into the bone after exposure of the skull. Injections were performed with coordinates in relation to bregma ( $y: 3$ $\mathrm{mm} ; x: 2.55 \mathrm{~mm} ; z$ : stepwise application of the rAAV between 2 and 3 $\mathrm{mm}$ ) using glass electrodes (Hartwich et al., 2009; Murray et al., 2011). After removal of the pipette, the holes were closed with bone wax and the wound covered with contact adhesive (Vetbond, $3 \mathrm{M}$ ). Finally, animals were supplied with postoperative analgesia (buprenorphine, $0.01 \mathrm{ml}$ per $10 \mathrm{~g}$ body weight; Reckitt Benckiser Healthcare). Selective expression of ChR2-tdT in SOM-Cre cells emerged as early as $3 \mathrm{~d}$ after rAAV injection and reached high expression profiles $\sim 10 \mathrm{~d}$ after injection (Murray et al., 2011). Acute slices $(300 \mu \mathrm{m})$ were prepared from injected mice $>10 \mathrm{~d}$ after injection. Pulses of blue light ( $473 \mathrm{~nm} ; 2 \mathrm{~ms}$; CoolLED System) with a diameter of $\sim 40 \mu \mathrm{m}$ were applied to the molecular layer in slices of SOM-Cre mice to recruit axon fibers from presynaptic $\mathrm{SOM}^{+}$neurons during whole-cell recordings of BCs. Recording pipettes were filled with a solution containing the following (in $\mathrm{mM}$ ): K-gluconate 140 , $\mathrm{KCl} 4$, HEPES 5, $\mathrm{MgCl}_{2}$ 2, $\mathrm{Na}_{2}$ ATP 4, EGTA 0.1, Na-GTP 0.5, Naphosphocreatine 7 and $0.2 \%$ biocytin ( $\mathrm{pH} 7.2 ; 290-310 \mathrm{mOsm})$. An extracellular stimulation pipette filled with $\mathrm{Na}^{+}$-rich HEPES-buffered solution was placed in the outer molecular layer to stimulate PPmediated inputs (pulse duration $0.1-0.4 \mathrm{~ms}, 5-10 \mathrm{~V}, 3$ pulses at $20 \mathrm{~Hz}$ ). The distance between the recorded interneuron and the stimulation pipette was $>100 \mu \mathrm{m}$ at the same depth as the recorded cell. Stimulus intensity was set to evoke no action potentials during the first stimulus but action potentials with a $\sim 50 \%$ probability during the second pulse. Intensity of blue light was set to a level that evoked an initial population IPSC with a mean peak amplitude similar to the size determined in SOM-BC recordings. First latency of action potential generation was measured as the time interval between the onset of the extracellular PP stimulation artifact and the threshold-crossing of the action potential $\left(\mathrm{V}_{\text {thres }}\right)$ defined as the first point in the voltage trajectory at which the voltage-change exceeded $20 \mathrm{Vs}^{-1}$ (Bekkers and Delany, 2001). The halfduration of mean EPSPs was defined as the time window between the rise and the decay of the signal halfway to the maximal amplitude of EPSPs. The peak amplitude was calculated in relation to the preceding baseline.

Data analysis. Input resistance $\left(\mathrm{R}_{\mathrm{in}}\right)$ was measured under voltageclamp conditions from the injected current induced by a $200 \mathrm{~ms}, 10 \mathrm{mV}$ voltage pulse. Membrane potentials reported in the text were not corrected for the junction potential. Half-duration of single action potentials evoked during paired recordings was measured during the first 10 ms of current injection $(300-700 \mathrm{pA})$ from $\mathrm{V}_{\text {thres }}$. Accommodation ratio was calculated by dividing the last by the first interspike interval in trains of action potentials evoked by long-lasting depolarizing current injections $(0.5-0.7 \mathrm{nA}, 1 \mathrm{~s})$.

Functional properties of unitary IPSCs (uIPSCs) were determined from averages of 30-50 traces, including failures. IPSCs were aligned to the steepest point in the rise of the presynaptic action potential during paired recordings. The synaptic latency was determined as the time interval between the steepest point in the rise of the presynaptic action potential and the onset of the postsynaptic UIPSC; the onset point was determined from the intersection of a line through the $20 \%-80 \%$ rise time of uIPSCs and the baseline. The peak amplitude was defined as the 
maximum response within a $1-4 \mathrm{~ms}$ window after the presynaptic action potential. The decay of average uIPSCs was fitted with the sum of two exponentials $\left[A \exp \left(-t / \tau_{1}\right)+B \exp \left(-t / \tau_{2}\right)\right]$, using a nonlinear leastsquares fit algorithm; time constants are reported as amplitude-weighted means $\left[\tau_{\mathrm{w}}=\left(A \tau_{1}+B \tau_{2}\right) /(A+B)\right]$. A trace was classified as a failure when the amplitude at the expected peak time, determined on the basis of the averaged IPSC (2-4 ms duration after the presynaptic action potential), was less than three times the SD of the baseline, measured in a $5 \mathrm{~ms}$ window preceding the IPSC. Coefficients of variation $(\mathrm{CV} ; \mathrm{SD} / \mathrm{mean})$ of synaptic latencies of uIPSCs were calculated from individual 30-50 traces. From these values, the SD and mean of the synaptic latency from individual uIPSCs was calculated. Data were analyzed using custommade software (Stimfit 0.13.2, https://code.google.com/p/stimfit/, courtesy of C. Schmidt-Hieber, University College London, and P. Jonas, IST Austria).

Statistical analysis was performed using SigmaPlot 11 (Systat Software). Values are given as mean \pm SEM. Statistical differences in the means of two samples were assessed by a two-tailed unpaired or a paired $t$ test for independent and related sample sets, respectively, if the samples were normally distributed as determined by the Shapiro-Wilk test. If the normality test failed or the number of tested experiments was $\leq 5$, the nonparametric Mann-Whitney $U$ test was used. If three datasets were compared for significant differences, a Dunn's one-way ANOVA was performed. Significance levels are indicated as $p$ values.

Immunohistochemistry and morphology. For immunohistochemical double-labeling of biocytin-filled cells, slices were fixed in 4\% PFA overnight. After washing in phosphate buffer $(\mathrm{PB}, 0.1 \mathrm{M})$ and then phosphatebuffered saline $(0.9 \% \mathrm{NaCl}$ in $0.025 \mathrm{M} \mathrm{PB} ; \mathrm{pH} 7.3)$, slices were incubated with primary antibodies against the following: (1) PV (polyclonal rabbit, 1:1000; or monoclonal mouse, 1:1000; both Swant); and (2) SOM (monoclonal rabbit, 1:500, Peninsula Laboratories) or CCK (monoclonal mouse, 1:2000, courtesy of G. Ohning, CURE, University of California, Los Angeles) in PBS containing 5\% goat serum, $0.3 \%$ Triton X-100, and $0.05 \% \mathrm{NaN}_{3}$ for either 24 or $72 \mathrm{~h}$ at $4^{\circ} \mathrm{C}$. The visualization of PV, SOM, or CCK labeling was performed with the secondary antibodies goat anti-rabbit Cy3 (1:1000, Jackson ImmunoResearch Laboratories) and goat anti-mouse 488 (1:1000, Invitrogen). Secondary antibodies were applied together with streptavidin conjugated with AlexaFluor-647 or AlexaFluor-750 (1:500, Invitrogen) in PBS, $0.1 \%-0.3 \%$ Triton X-100 and $0.05 \% \mathrm{NaN}_{3}$ for $6-12 \mathrm{~h}$ at $22^{\circ} \mathrm{C}$ or $24 \mathrm{~h}$ at $4^{\circ} \mathrm{C}$. Slices were washed in PBS, then PB, and embedded in Mowiol or VectorMount (Vector Laboratories). Fluorescent labeling with $4^{\prime}$,6-diamidino-2-phenylindole (1: 1000) was performed in some slices to stain nuclei.

In a subset of pairs, biocytin-filled cells were fixed in 2.5\% PFA, $1.25 \%$ glutaraldehyde, and $15 \%$ picric acid in $0.1 \mathrm{M} \mathrm{PB}\left(12 \mathrm{~h}, 4^{\circ} \mathrm{C}\right)$. After fixation, slices were treated with hydrogen peroxide $(1 \%, 10 \mathrm{~min})$ and rinsed in PB. After incubation in $10 \%$ and $20 \%$ sucrose solution, slices were snap-frozen in liquid nitrogen and thawed at room temperature. Then they were transferred to PBS containing $1 \%$ avidin-biotinylated HRP complex (ABC; Vector Laboratories) for $\sim 12 \mathrm{~h}$. Slices were rinsed in $\mathrm{PB}$ and developed with $0.05 \%$ 3,3-diaminobenzidine tetrahydrochloride $(\mathrm{DAB})$ and $0.01 \%$ hydrogen peroxide. Finally, they were rinsed several times in PB and embedded in Mowiol (Sigma-Aldrich).

Fluorescently labeled neurons were examined on a confocal microscope (Zeiss LSM 710 or Olympus Fluoview, 1000) using a $20 \times$ objective lenses (NA 0.8) to obtain overview images and a $63 \times$ oil-immersion objective (NA 1.4) for evaluating putative synaptic contacts. In a subset of labeled interneurons, detailed reconstructions of the dendritic and axonal arbours were performed using Fiji-ImageJ and the Simple Neurite Tracer plugin (http://fiji.sc/Simple_Neurite_Tracer) (Longair et al., 2011). DAB-labeled cells were examined using an Olympus microscope with a $20 \times$ and $63 \times$ oil-immersion objective lenses and reconstructed using Neurolucida software (MicroBrightfield Bioscience). Morphological criteria were applied to identify all presynaptic and postsynaptic cells in this study (Hosp et al., 2013). In a subset of labeled cells, their neurochemical content was additionally confirmed (PV, 17 of 21 tested BCs; SOM, 10 of 12 tested HIPP cells; CCK, 5 of 5 tested HICAP cells). We did not observe any CCK labeling in identified BCs in our sample (6 of 6 tested BCs). Data analysis was performed on a total of 50 identified synaptically connected pairs of interneurons. PV-positive $\left(\mathrm{PV}^{+}\right)$interneurons comprise BCs and AA cells (Freund and Buzsáki, 1996; Klausberger and Somogyi, 2008) but no cell with light-microscopic feature of the latter (axonal arbor shifted toward the hilus, axon cartridges corresponding to boutons along an axon initial segment) was observed in our sample. This finding is consistent with a low percentage of AA cells among $\mathrm{PV}^{+}$neurons in the DG (Hu et al., 2010). The probability of synaptic connections among interneuron types was defined as the percentage of identified interneuron-interneuron connections in relation to the total number of simultaneous dual recordings from morphologically and/or physiologically identified interneuron types. HICAP cells show in contrast to other DG interneuron types a marked adaptation and a reduction in the amplitude of action potentials after the second or third spike during large-amplitude current injections $(0.6-0.9 \mathrm{nA}, 1 \mathrm{~s})$, which partially recover in the later phase of the train (Fig. $1 A_{2}$, inset). This criterion was used for HICAP-like cell identification if morphology was not available and used for determining connection probabilities for this interneuron type. All dual recordings have been performed from cells with soma-to-soma distances of $\leq 70 \mu \mathrm{m}$. Putative synaptic contacts were identified as close appositions between an axonal varicosity and a dendrite or the soma in the same focal plane. Confocal images from putative contacts were deconvolved for better optical resolution using a point spread function provided by Huygens core software (Scientific Volume Imaging). In one DAB-labeled HICAP-HICAP pair, lightmicroscopically identified synapses were further examined using electron microscopy following protocols described previously (Bartos et al., 2001).

\section{Results}

Morphological, immunohistochemical, and physiological identity of three major dentate gyrus interneuron types

To examine the functional characteristics of GABAergic synapses targeting interneurons, we performed whole-cell patch-clamp recordings of synaptically coupled pairs of identified DG interneurons in acute hippocampal slices at near-physiological temperature $\left(31^{\circ} \mathrm{C}-32^{\circ} \mathrm{C}\right.$ ). All 50 cell pairs (38 pairs in rat, 12 pairs in mouse slices) analyzed in this study were biocytin-filled during recordings and visualized post hoc using AlexaFluor-647conjugated streptavidin to obtain their morphological identity (Fig. 1; see Materials and Methods). A subset of recorded cells were further neurochemically characterized using immunofluorescent double-labeling against the three major interneuron markers PV, CCK, and SOM (Freund and Buzsáki, 1996). Morphological analysis revealed three major subtypes of synaptically interacting DG interneurons (Fig. 1A): (1) BCs with axon collaterals extending into the granule cell layer ( 12 cells from $6 \mathrm{BC}-\mathrm{BC}$ pairs; Fig. $1 A_{1}$ ) (Bartos et al., 2001, 2002); (2) HICAPs (Han et al., 1993; Halasy and Somogyi, 1993; Hosp et al., 2013) with axonal fibers projecting in the inner molecular layer contacting the proximal domains of target dendrites with few collaterals extending in the granule cell layer (<20\%) (Hosp et al., 2013), suggesting the formation of some somatic synapses (30 cells from 15 HICAPHICAP pairs; Figs. $1 A_{2}$ and $3 A$ ); and (3) HIPPs (Han et al., 1993; Halasy and Somogyi, 1993; Hosp et al., 2013) with axonal arbors covering large areas of the outer and middle molecular layer and few collaterals extending into the hilus ( 12 cells from 6 HIPPHIPP pairs; Figs. $1 A_{3}$ and $3 B$ ). Immunolabeling revealed that $\mathrm{BCs}$ contained PV ( 12 cells form $6 \mathrm{BC}-\mathrm{BC}$ pairs; Fig. $1 A_{1}$ ), whereas HICAPs expressed CCK ( 5 of 5 tested cells; Fig. $1 A_{2}$ ) and HIPP cells commonly expressed SOM (10 cells of 6 HIPP-HIPP pairs; Fig. $1 A_{3}$ ). The dendritic arbors of BCs and HICAPs extended into the entire molecular layer and the hilus, indicating that they plausibly receive excitatory synaptic inputs from both afferent and recurrent collaterals, providing feedforward and feedback inhibition to the DG network. In contrast, dendrites of HIPP cells were 

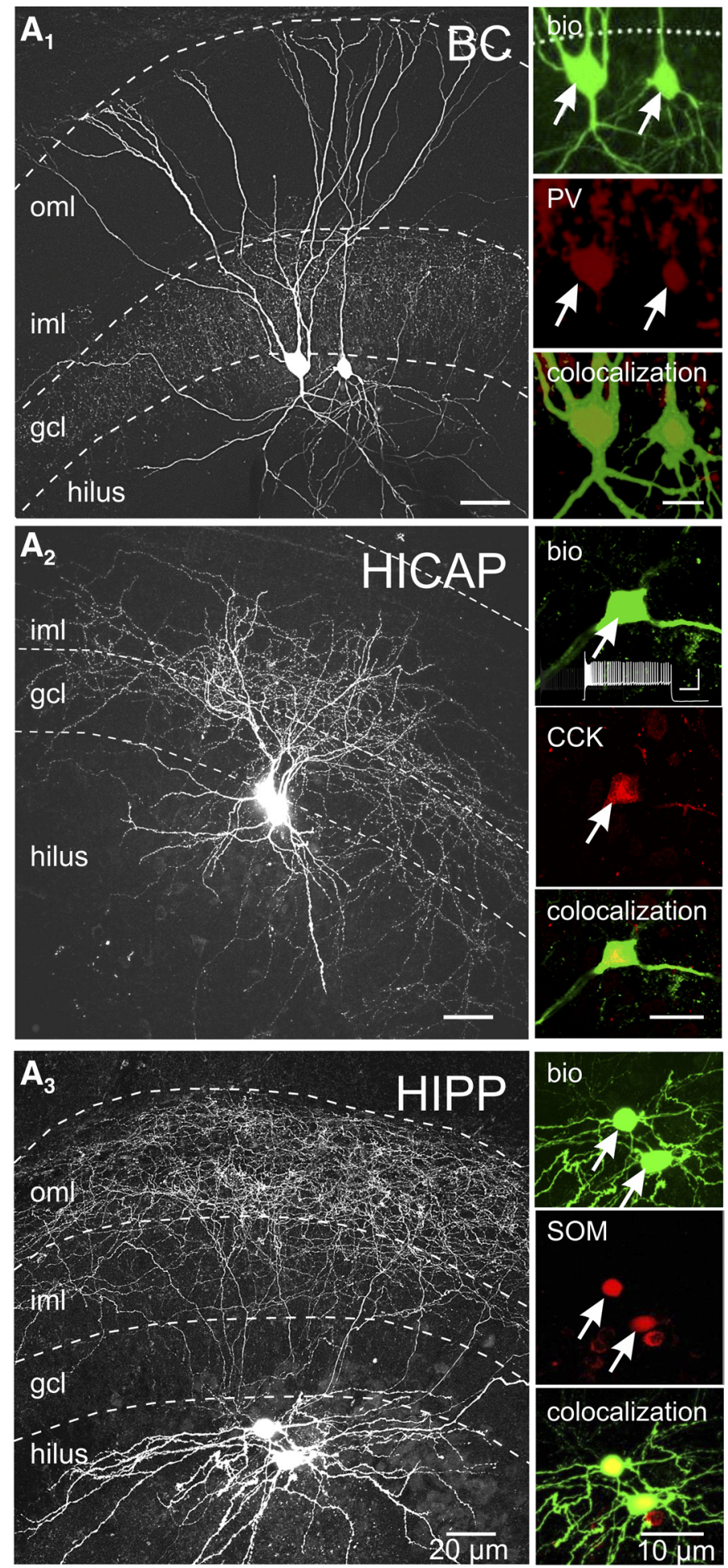

$B_{1}$
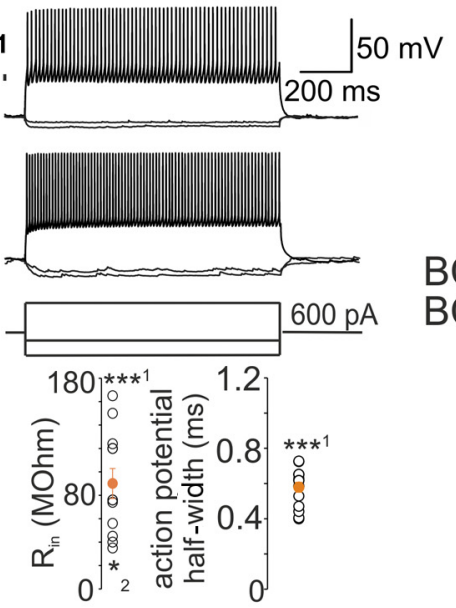

$B_{2}$
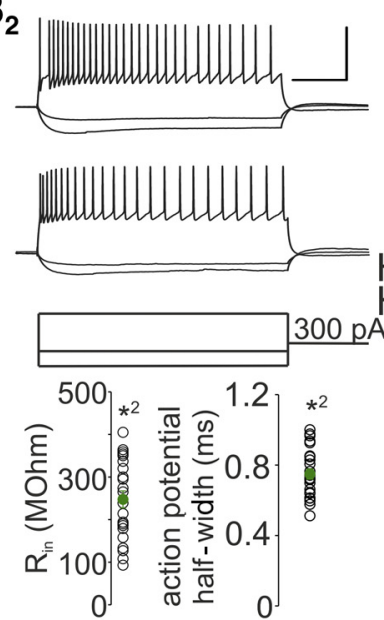

$\mathrm{B}_{3}$
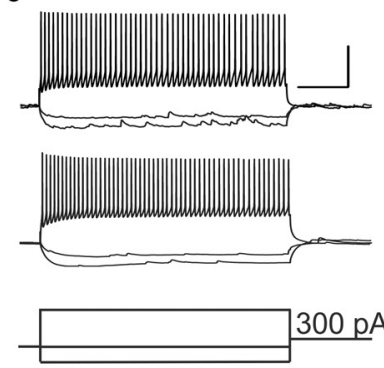

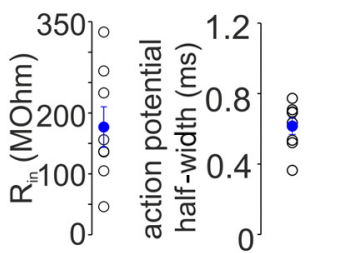
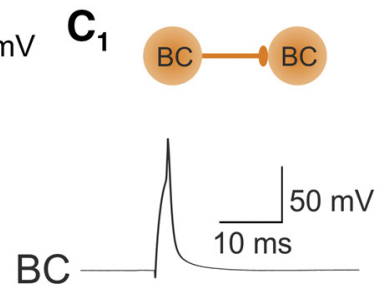

$\mathrm{BC}$

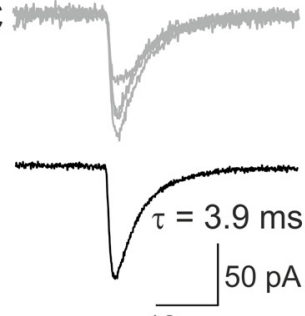

$10 \mathrm{~ms}$

$\mathrm{C}_{2}$

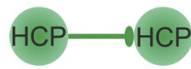

$\mathrm{C}_{3}$

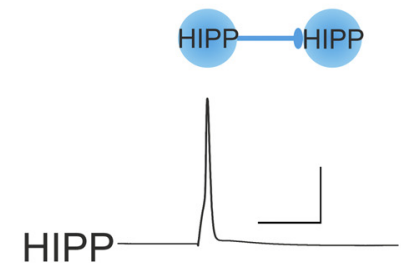

HIPP

$B C$

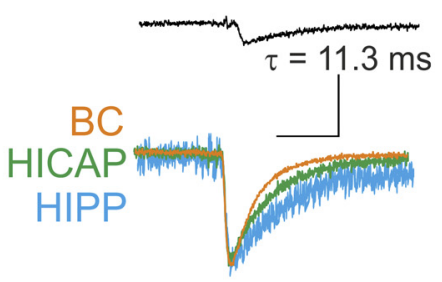

Figure 1. Morphological, physiological, and synaptic characteristics of perisomatic and dendritic inhibitory interneurons in rodent dentate gyrus. A, Left, Confocal image stacks of pairs of synaptically connected GABAergic interneurons intracellularly labeled with biocytin and visualized with streptavidin conjugated with AlexaFluor-647 (white labeling). $\boldsymbol{A}_{\boldsymbol{1}}$, Perisomatic inhibitory interneurons with axon arbours located in the granule cell layer ( $\mathrm{gcl}$ ). Right, Both perisomatic inhibitory BCs are PV-positive as revealed by antibody labeling. From top to bottom, top green, biocytin labeling, arrows point to both somata; middle red, PV expression; bottom, colocalization of both markers. $A_{2}$, HICAPs with axon collaterals mainly located in the inner molecular layer (iml). Right, A single intracellularly labeled HICAP cell was identified as CCK-positive. Biocytin was visualized by streptavidin conjugated to AlexaFluor-750. Inset, Characteristic discharge pattern of the HICAP cell $(0.7 \mathrm{nA}, 1 \mathrm{~s})$. Calibration: $200 \mathrm{~ms}, 50 \mathrm{mV} . \boldsymbol{A}_{3}$, HIPPs with axon arbors located predominantly in the outer molecular layer (oml). Right, Both neurons coexpress somatostatin (SOM; arrows). $\boldsymbol{B}$, Passive and active membrane properties of identified $B C s\left(\boldsymbol{B}_{1}\right)$, HICAPs $\left(\boldsymbol{B}_{2}\right)$, and HIPPs $\left(\boldsymbol{B}_{3}\right) \cdot \boldsymbol{B} 1-\boldsymbol{B} 3$, Top traces, Voltage trajectories of cell pairs shown in $\boldsymbol{A}$ during 1-s-long current injections $(-100,-50,300-800 \mathrm{pA}) \cdot \boldsymbol{B}_{1}-\boldsymbol{B}_{\boldsymbol{B}}$, Summary graphs show left the input resistance $\left(\mathrm{R}_{\mathrm{in}}\right)$ of the recorded cell types and right the half-duration of single action potentials. Each circle represents a single data point; colored circles with lines represent mean values \pm SEM. C, uIPSCSrecorded at pairs shown in A. A presynaptic action potential (top) evokes uIPSCs in the postsynapticcell. Single ulPSCs (6 traces) are shown superimposed (middle), and the average uIPSC (30 traces) at $-70 \mathrm{mV}$ is shown (bottom). Schematic illustration on top represents the recoded neuron types; orange represents BC-BC; green represents HICAP-HICAP; blue represents HIPP-HIPP pairs. $C_{3}$, Bottom, Average uIPSCs shown in C1-C3 were peak normalized and superimposed. ${ }^{* *} p \leq 0.001 .{ }^{* *} p \leq 0.01 .{ }^{*} p \leq 0.05$. ${ }^{1}$ Significantly different from HICAP. ${ }^{2}$ Significantly different from HIIPP. 
A
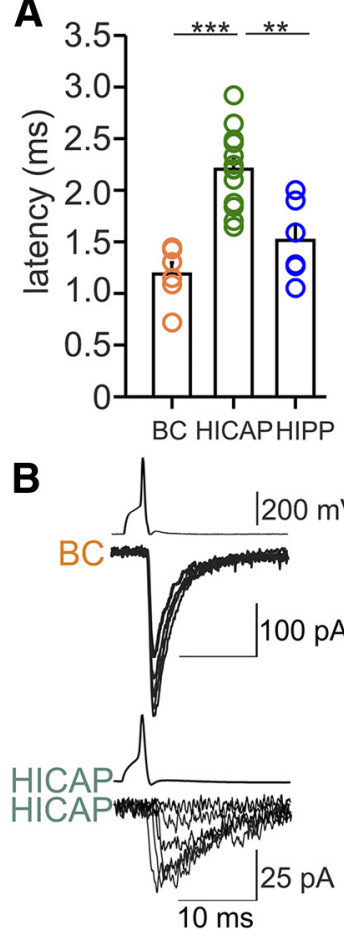
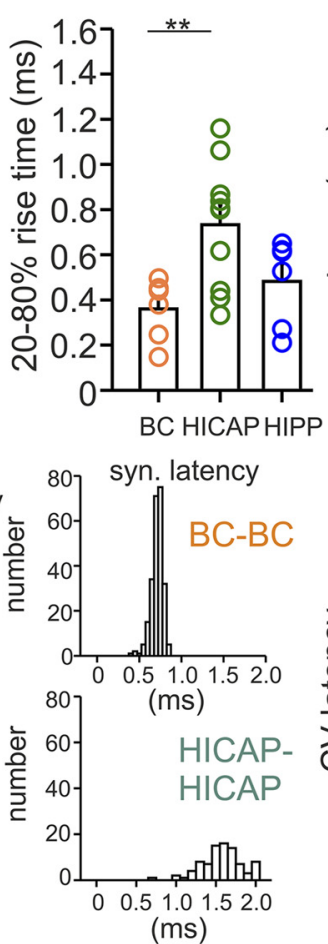
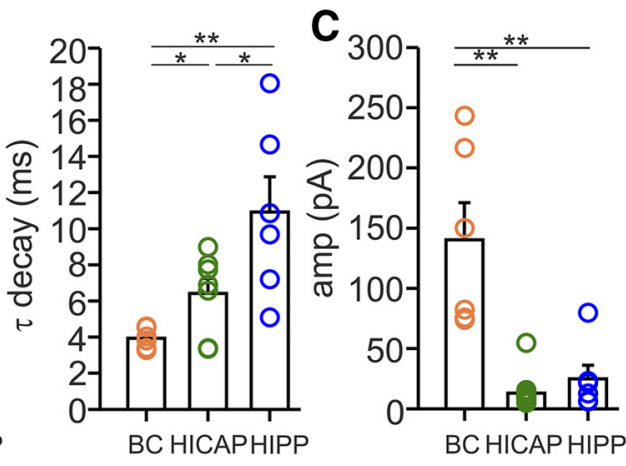

D

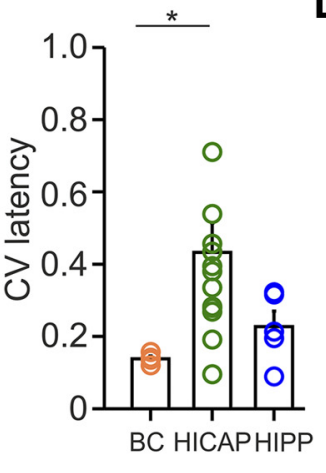

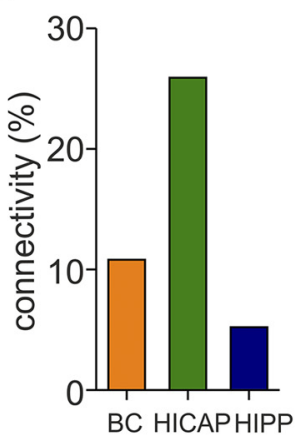

Figure 2. Weak, unreliable, and slow inhibition at homologous interneuron output synapses. A, Summary graph of synaptic latency, $20 \%-80 \%$ rise time, and decay time constant ( $\tau$, amplitude weighted decay time defined with a biexponential fit) of uIPSCs at BC-BC (6 pairs), HICAP-HICAP (15 pairs), and HIPP-HIPP (6 pairs) synapses. All cells were morphologically identified. Values are averages of $>30$ traces, including failures. ${ }^{* *} p \leq 0.01 .{ }^{*} p \leq 0.05 . B$, Left, Superposition of five traces shows differences in the timing of single ulPSCs at BC-BC and HICAP-HICAP synapses. Middle, Summary histogram of synaptic latencies from representative BC-BC (top) and HICAP-HICAP (bottom) pairs. Right, Summary bar graph of the CV of synaptic latency. Note the larger jitter in the timing of uIPSCs at HICAP-HICAP synapses. C, Summary bar graph of peak amplitudes of average uIPSCs, including failures. D, Probability of possible unidirectional synaptic connections among homologous interneuron types (10.7\% BC-BC, 6 pairs of 56 simultaneous dual BC recordings; $25.9 \%$ HICAP-HICAP, 15 pairs of 58 simultaneous dual HICAP cell-like recordings; and 5.2\% HIPP-HIPP, 6 pairs of 115 dual SOM-GFP cell recordings). Error bars indicate mean \pm SEM. Circles represent single data points. ${ }^{* *} p \leq 0.001 .{ }^{* *} p \leq 0.01 .{ }^{*} p \leq 0.05$.

mostly restricted to the hilus supporting their proposed primary role as feedback inhibitory cells (Figs. $1 A_{3}$ and $3 B$ ) (Han et al., 1993; Freund and Buzsáki, 1996).

Physiological hallmarks of BCs are a low $\mathrm{R}_{\text {in }}(90.1 \pm 13 \mathrm{M} \Omega ; 12$ cells) and the ability to discharge trains of brief action potentials $(0.6 \pm 0.03 \mathrm{~ms})$ at high frequency $(145.3 \pm 3.9 \mathrm{~Hz})$ with low accommodation ratios ( $\mathrm{r} \geq 0.7$; Fig. $1 B_{1}$; see Materials and Methods) (Rudy and McBain, 2001). In contrast, HICAPs showed a 2.6 -fold higher $\mathrm{R}_{\text {in }}\left(22\right.$ cells; $233.9 \pm 21 \mathrm{M} \Omega, p=0.001$; Fig. $\left.1 B_{2}\right)$ and the single action potential was broader $(0.75 \pm 0.03 \mathrm{~ms}, p=$ 0.002 ). HIPP cells showed intermediate physiology with a twofold higher $\mathrm{R}_{\mathrm{in}}$ than BCs (7 cells; $176.9 \pm 33 \mathrm{M} \Omega, p=0.017$ ) but 1.3 -fold lower $\mathrm{R}_{\text {in }}$ than HICAPs $\left(p=0.01\right.$; Fig. $\left.1 B_{3}\right)$. The halfduration of single action potentials was similar between BCs and HIPPs $(0.65 \pm 0.06 \mathrm{~ms}, p=0.164)$ but narrower in HIPP than HICAPs $\left(p=0.046\right.$; Fig. $\left.1 B_{2}, B_{3}\right)$. Finally, both HIPP and HICAPs displayed firing patterns at significantly lower frequency than BCs (HICAP: $68.3 \pm 2.9 \mathrm{~Hz}, p<0.001$; HIPP: $107.7 \pm 4.4 \mathrm{~Hz}$, $p<0.001)$ with markedly stronger accommodation in HICAPs than in HIPPs ( $r \leq 0.55$ vs $0.55<\mathrm{r}<0.7$ ). Thus, BCs, HICAP, and HIPP cells could be unequivocally identified on the basis of their morphological, neurochemical, and physiological properties.

\section{High specificity in the functional properties of inhibitory} signaling at homologous interneuron-interneuron synapses Our morphological and physiological analyses revealed two major types of interneurons connected by homologous inhibitory synapses: HICAP-HICAP and HIPP-HIPP pairs.
HICAP-HICAP cells were connected with a probability of $25.9 \%$ (15 unidirectional pairs of 58 simultaneous dual recordings; see Materials and Methods) and HIPP-HIPP cells with a probability of 5.2\% (6 unidirectional pairs of 115 dual recordings from SOMGFP cells; Fig. 2D). No synaptic connections were found between physiologically identified HICAP- and HIPP-like neurons (30 dual recordings; see Materials and Methods). A comparison between the functional properties of putative perisomatic $\mathrm{BC}-\mathrm{BC}$ synapses $(10.7 \%$ BC-BCs, 6 pairs of 56 dual BC recordings; Fig. $2 D)$ with the signaling characteristics of the two types of homologous synapses among HICAPs and HIPPs revealed several differences (Figs. $1 C$ and 2). Consistent with our previous findings (Bartos et al., 2001, 2002, 2007), uIPSCs at BC-BC synapses were evoked after short latencies $\left(1.2 \pm 0.1 \mathrm{~ms} ; 6\right.$ pairs; Figs. $1 C_{1}$ and $2 A)$ with large mean amplitudes $(140.2 \pm 30.8 \mathrm{pA})$ and fast time courses $(20 \%-80 \%$ rise time $0.4 \pm 0.06 \mathrm{~ms}$; amplitude weighted decay time constant $\tau=3.9 \pm 0.2 \mathrm{~ms}$ ). Precision of GABA release, defined as the $\mathrm{CV}$ of the synaptic latency, was very high with a value of $0.14 \pm 0.007$ (Fig. $2 B$ ). Moreover, the failure rate of inhibitory signals at BC-BC synapses was low at $1.7 \pm 1.7 \%$, indicating a high reliability in GABA release (data not shown). In comparison, uIPSCs at HICAP-HICAP synapses were induced after a 1.8-fold longer synaptic latency $(2.2 \pm 0.1 \mathrm{~ms} ; 15$ pairs; $p=$ 0.001 ; Fig. $2 A)$ with 10.9-fold smaller amplitudes $(12.9 \pm 3.9 \mathrm{pA}$, $p=0.002$; Fig. $2 C$ ) and slower time courses than at BC-BC synapses. The rise time was 1.8 times longer $(0.7 \pm 0.09 \mathrm{~ms}, p=$ 0.025; Fig. $2 A)$ and the decay time by a factor of 1.6 slower $(\tau=$ $6.4 \pm 0.8 \mathrm{~ms} ; p=0.036$; Fig. $2 A$ ). The $\mathrm{CV}$ of the synaptic latency was 3.1 times higher at HICAP-HICAPs with $0.43 \pm 0.08(p=$ 
0.015; Fig. $2 B)$ in line with previous studies examining $\mathrm{CCK}^{+}$ interneuron to principal cell synapses in rat DG (Hefft and Jonas, 2005) and area CA1 (Maccaferri et al., 2000). Finally, the failure rate of inhibitory signals was by a factor of 33.7 higher $(57.2 \pm$ $6.5 \%, p<0.001$ ), indicating a low reliability in GABA release at HICAP-HICAP synapses.

Interestingly, similarities in the properties of synaptic transmission were evident between BC-BC and HIPP-HIPP connections. Inhibitory signals at HIPP-HIPP synapses were evoked after a similar short mean latency $(1.5 \pm 0.16 \mathrm{~ms}, 6$ pairs; $p=$ 0.252 ; Fig. $2 A)$ with a low $C V(0.2 \pm 0.04, p=0.343$; Fig. $2 B)$, indicating high precision in GABA release. Finally, the mean rise time of uIPSCs was short $(0.5 \pm 0.08 \mathrm{~ms}$; Fig. $2 A)$ comparable to $\mathrm{BC}-\mathrm{BC}$ pairs, indicating high synchrony in GABA release. Three differences in synaptic transmission were, however, also apparent. First, the percentage of failures in inhibitory signaling was 29.7-fold higher than at BC-BC synapses $(50.4 \pm 6.1 \%, p=$ 0.009; data not shown). Second, the mean amplitude of uIPSCs was 5.6 times smaller $(25.0 \pm 11.3 \mathrm{pA}, p=0.002$; Fig. $2 C)$, a difference that persisted even if failures were excluded from average uIPSCs (data not shown). Third, the decay of uIPSCs was 2.8 -fold slower $(10.9 \pm 1.9 \mathrm{~ms}, p=0.009$; Fig. $2 A)$. GABAergic transmission at both HIPP-HIPP and HICAP-HICAP synapses could be blocked by $10 \mu \mathrm{M}$ SR95531 (94 $\pm 2.5 \%$, 4 tested pairs; data not shown), indicating that slow inhibition was mediated by $\mathrm{GABA}_{\mathrm{A}}$ receptors. Thus, in contrast to $\mathrm{BC}$-mediated inhibition, signaling at HIPP and HICAP output synapses is in general weaker, less reliable, and slower. However, a high specificity in the functional properties of inhibitory synapses exists among homologous interneuron pairs.

Some of the observed differences and similarities in synaptic signaling can be explained by morphological criteria. The synaptic latency is defined by two components: (1) a delay based on the axonal length between synaptically connected neurons as well as the velocity of action potential conduction; and (2) a delay inherent to the transmitter release process. Although spike propagation along the interneuron axon may not be constant throughout its entire length, our recordings have been performed at closely spaced cell pairs (intersomatic distance $<70 \mu \mathrm{m}$ ). We therefore assumed short axonal distances between communicating BCs with perisomatic inputs, which will result in short synaptic latencies (Bartos et al., 2001; Bartos and Elgueta, 2012). In contrast, axonal distributions of HICAPs in the inner molecular layer indicated a proximal dendritic synapse location (Fig. $1 A_{2}$ ). Indeed, we observed a 1.8-fold larger synaptic latency at HICAP-HICAP pairs, which indicated longer axonal propagation time of somatically evoked action potentials. A single reconstruction with subsequent electron-microscopic analysis revealed five synaptic contacts of a presynaptic HICAP at proximal dendritic compartments of a postsynaptic HICAP (Fig. 3A) (Leranth and Frotscher, 1986). Surprisingly, the mean synaptic latency of uIPSCs recorded at HIPP-HIPP connections was similar to those obtained from $\mathrm{BC}-\mathrm{BC}$ pairs, suggesting the formation of perisomatic synapses. Consistent with this hypothesis, light microscopic examination identified axonal bouton-like structures in the hilus in close apposition to primary dendrites close to the HIPP soma (3 HIPP-HIPP pairs; Fig. 3B). Moreover, dendrites of HIPP cells were located in the hilus and granule cell layer but rarely in the molecular layer (Fig. 3B) (Hosp et al., 2013). Thus, some of the highly specific functional properties of homologous inhibitory synapses can be explained by anatomical characteristics of the interneuron types.
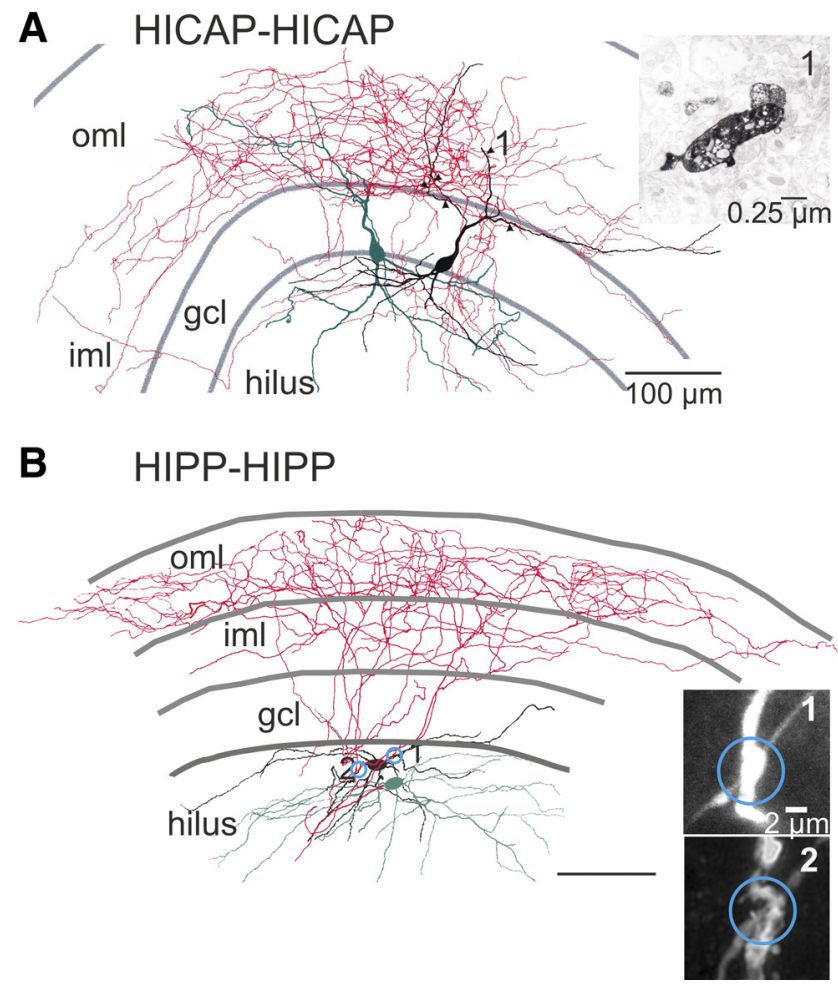

Figure 3. Reconstructions of homologous pairs of synaptically connected HICAPs and HIPPS. Soma and dendrites of the presynaptic neuron are depicted in green, and the axon is shown in red. Soma and dendrites of the postsynaptic neuron are drawn in black and the axon was left out for clarity. $A$, Neurolucida reconstruction of a DAB-labeled HICAP-HICAP pair. Arrowheads point to synaptic contact sites validated by electron microscopy. Inset, One of five identified synaptic sites. Number relates to the location of the depicted synapse. $\boldsymbol{B}$, Simple neurite tracer reconstruction of a HIPP-HIPP pair (same as in Fig. $1 A_{3}$ ). Insets, Deconvolved confocal image stacks of 2 visually identified putative contact sites. Blue circles and numbers represent areas in which the putative synapses are located. They were identified as close appositions between the presynaptic axon and the postsynaptic dendrite. Gray lines indicate borders between layers. oml, outer molecular layer; gcl, granule cell layer; iml, inner molecular layer.

\section{High specificity in the dynamic properties in inhibitory signaling at HIPP-HIPP and HICAP-HICAP synapses}

During explorative behavior, the DG generates $\theta(4-12 \mathrm{~Hz})$ modulated $\gamma(30-100 \mathrm{~Hz})$ activity patterns (Bragin et al., 1995; Leutgeb et al., 2007). We therefore examined the dynamic properties of GABA release at interneuron-interneuron synapses by evoking short bursts of trains of 10 action potentials at $50 \mathrm{~Hz}$ in the presynaptic cell and recording the corresponding uIPSCs in the target cell. The data were compared with $\mathrm{BC}-\mathrm{BC}$ paired recordings (Fig. 4). Similar to our previous investigations (Bartos et al., 2001, 2002), synaptic transmission at BC-BC synapses was characterized by short-term depression (Fig. $4 A$ ) with an average $\mathrm{uIPSC}_{10} / \mathrm{uIPSC}_{1}$ ratio of $0.46 \pm 0.1$ ( 6 pairs; Fig. $4 B$ ). In contrast, GABA release at HICAP-HICAP synapses showed robust shortterm facilitation with a mean $\mathrm{uIPSC}_{10} / \mathrm{uIPSC}_{1}$ ratio of $1.6 \pm 0.4$ (10 pairs; Fig. 4B). HIPP-HIPP responses were biphasic, consisting of an initial strongly facilitating phase, which reached a maximum at the fifth uIPSC ( 5 pairs; uIPSC $_{5} /$ uIPSC $_{1}: 2.4 \pm 0.3$ ) followed by a second phase, resulting in a moderate decline in IPSC size relative to the initial facilitation $\left(\mathrm{uIPSC}_{10} / \mathrm{uIPSC}_{1}\right.$ : $1.4 \pm 0.5$; Fig. $4 A, B)$.

To determine whether these signaling dynamics are caused by presynaptic (e.g., depletion of the vesicular pool) (Stevens and Tsujimoto, 1995) or postsynaptic mechanisms (e.g., GABA $\mathrm{A}$ receptor desensitization) (Jones and Westbrook, 1996), we per- 


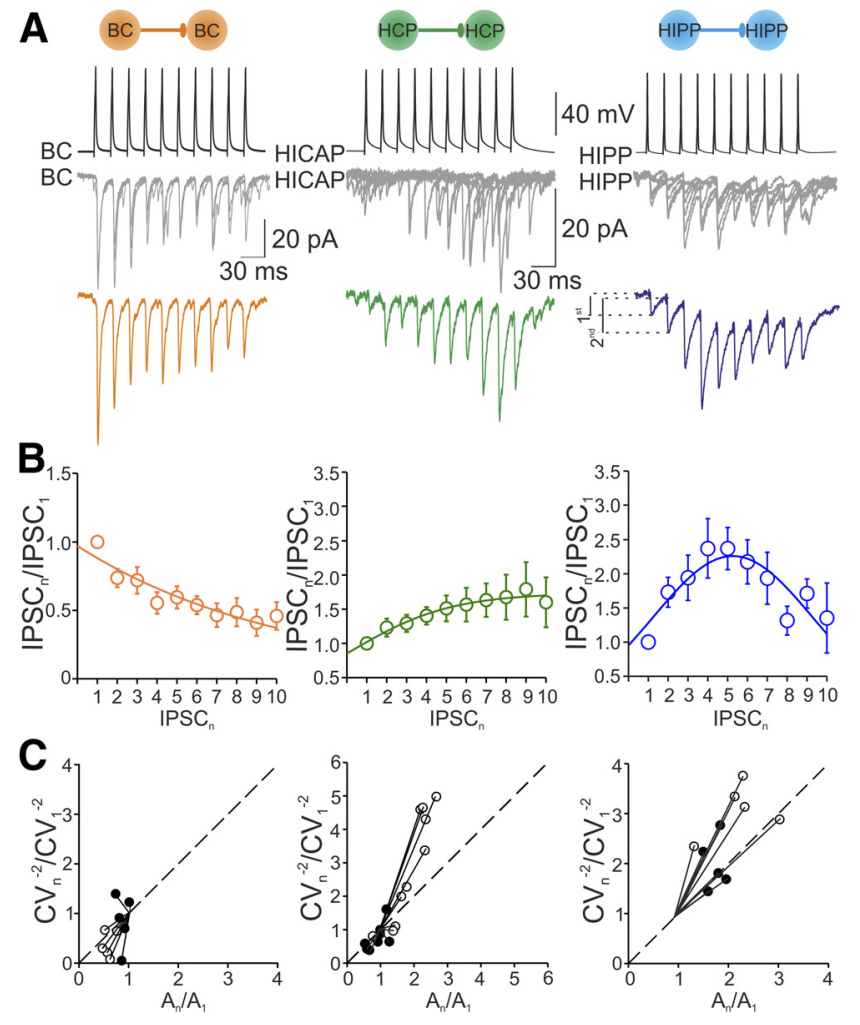

Figure 4. Dynamic properties of GABA release at homologous BC- versus HICAP- and HIPPmediated inhibitory output synapses. $\boldsymbol{A}$ Left, Multiple-pulse depression at $B C-B C$ synapses. Top, Ten action potentials were evoked at $50 \mathrm{~Hz}$ in the presynaptic BC. Bottom, Superposition of 6 traces of uIPSCs. Average trace of uIPSCs from 30 individual traces (failures included). Middle, Multiple-pulse facilitation at HICAP-HICAP synapses. Same experiment as at BC-BC synapses. Note the asynchronously evoked uIPSCs during the course of the train. Right, HIPP-HIPP synapses show a biphasic response upon repetitive activation of the presynaptic cell. The initial strong multiple-pulse facilitation is followed by a decline in facilitation. Dashed lines indicate that uIPSC amplitudes were measured from the preceding baseline. $\boldsymbol{B}$, Summary plots represent amplitude ratios between IPSC $C_{n}$ to IPSC ${ }_{1}$ plotted as a function of the subsequently evoked uIPSC in the train. Lines represent fit results to the data (left and middle, exponential function; right, parabolic function). C, CV analysis of multiple-pulse depression (left), multiple-pulse facilitation (middle), and biphasic response (right). The inverse of the square of the $\mathrm{CV}^{-2}$ of the amplitude of the second (open circles) and fourth uIPSC (filled circle) was plotted against the mean peak amplitude $\left(A_{n}\right)$; data were normalized to the $\mathrm{CV}^{-2}$ and mean amplitude of the first uIPSC $\left(\mathrm{CV}_{1}{ }^{-2}, \mathrm{~A}_{1}\right)$. Dashed line indicates the identity line (6 BC-BC, 10 HICAP-HICAP and 5 HIPPHIPP pairs).

formed a CV analysis of uIPSC amplitudes (Fig. 4C) (Malinow and Tsien, 1990). The inverse of the square of the CV for the second and forth uIPSC was plotted against the mean, and both values were normalized to the respective first uIPSC. Most of the data points were located at or below the identity line for BC-BC pairs and close or above the identity line for HICAP-HICAP and HIPP-HIPP pairs indicating presynaptic changes in multiplepulse modulation (Fig. 4C) (Bartos et al., 2001, 2002). Consistent with a presynaptic locus, the percentage of failures declined during the train and was 10.4-fold smaller at HICAP and 22.7 times smaller at HIPP output synapses for the 10th compared with the first uIPSC (HICAP 10th IPSC: $3.0 \pm 0.3 \%$ vs first IPSC: $31.2 \pm$ 9.7\%, $p=0.008$; HIPP 10th IPSC: $2.3 \pm 0.4 \%$ vs first uIPSC $52.1 \pm 4.5 \%, p=0.006)$. Thus, in contrast to the marked shortterm depression at BC output synapses, inhibitory signaling at homologous HICAP and HIPP synapses is characterized by a cell type-specific facilitation caused by presynaptic mechanisms (see also Ma et al., 2010, 2012).
Next, we examined the recovery from multiple-pulse dynamics by evoking single presynaptic action potentials with varying time delays after the end of the $50 \mathrm{~Hz}$ burst (Fig. 5). GABAergic transmission at BC-BC synapses recovered rapidly from depression with a time constant $(\tau)$ of $0.65 \mathrm{~s}$ when data were fit with a single exponential function (6 pairs; Fig. 5A). Full recovery was reached after $\sim 3 \mathrm{~s}$. In contrast, HICAP-mediated uIPSCs continued to facilitate up to $\sim 1.8 \mathrm{~s}$ after the end of the train, thereafter declined exponentially with a $\tau$ of $1.95 \mathrm{~s}$ and recovered from facilitation after $\sim 6 \mathrm{~s}$ ( 7 pairs; Fig. $5 B$ ). Finally, signaling at HIPP-HIPP synapses remained potentiated shortly for $\sim 0.2 \mathrm{~s}$ after the train, and complete recovery from facilitation was observed at $\sim 1.5 \mathrm{~s}$ with a $\tau$ of $0.36 \mathrm{~s}$ ( 5 pairs). Thus, inhibition between HICAP-HICAP and HIPP-HIPP cells remains potentiated after a burst. The duration of this short-term potentiation is, however, interneuron type-dependent.

\section{Functional properties of inhibitory signaling at heterologous interneuron-interneuron synapses}

In addition to connections obtained from homologous interneuron types, we observed a high probability of synaptically coupled interneuron-BCs (16.3\% HICAP-BCs, 15 pairs of 92 simultaneous dual recordings of physiologically identified HICAP-like and BC-like cells; $12.8 \%$ HIPP-BCs 12 pairs of 94 simultaneous dual recordings from SOM-GFP and BC-like cells; Fig. 6C; see Materials and Methods), which is in agreement with the high number of GABAergic synapses at apical dendritic domains of BCs (Gulyás et al., 1999). Although BCs were also connected to other interneuron types (13.3\% BC-HICAPs, 6 of 45 dual recordings, and $2.5 \%$ BC-HIPPs, 2 of 80 dual recordings), their functional and dynamic properties were similar to BC-BC connections (data not shown). Thus, we focused our analysis in the following on the functional characteristics of heterologous HICAP- and HIPP-mediated inhibitory synapses onto BCs and compared them with homologous HIPP-HIPP, HICAP-HICAP, and BC-BC connections (Fig. 6).

Signaling characteristics of HICAP-BCs were quite similar to HICAP-HICAP synapses. Conformities applied to the low synaptic strength and reliability in GABA release, indicating weak and unreliable inhibition (amplitude: $24.4 \pm 5.8 \mathrm{pA}$ vs $12.9 \pm 3.9$ $\mathrm{pA}$, respectively, $p=0.771$; failures: $48.3 \pm 5.3$ vs $57.2 \pm 6.5 \%$, respectively, $p=0.845)$. Furthermore, the mean synaptic latency (HICAP-BC: $2.1 \pm 0.1 \mathrm{~ms}$ vs HICAP-HICAP: $2.2 \pm 0.1 \mathrm{~ms} ; 8$ vs 15 pairs, $p=0.705$ ) as well as the mean rise time of uIPSCs (HICAP-BC: $0.69 \pm 0.06 \mathrm{~ms}$ vs HICAP-HICAP: $0.7 \pm 0.08 \mathrm{~ms}$, $p=0.762$ ) did not differ between both types of synapses (Figs. $2 A$ and $6 A$ ). This can be largely explained by the proposed same proximal dendritic synapse location (Fig. $3 A$ ). Moreover, precision in GABA release defined as the $\mathrm{CV}$ of synaptic latency was comparably low (HICAP-BC: $0.46 \pm 0.07$ vs HICAP-HICAP: $0.43 \pm 0.08, p=0.874$; Figs. $2 A$ and $6 B$ ). In contrast, some signaling properties of HIPP-BCs were markedly different from HIPP-HIPP synapses. The synaptic latency was 1.6-fold, and the rise time was 1.4 times longer at HIPP-BC than HIPP-HIPP synapses (latency: $2.1 \pm 0.2 \mathrm{~ms}, 6$ pairs vs $1.5 \pm 0.16 \mathrm{~ms}, 6$ pairs, respectively; $p=0.03$; rise time: $0.7 \pm 0.1 \mathrm{~ms}$ vs $0.4 \pm 0.06 \mathrm{~ms}$, respectively, $p=0.05$; Figs. $2 A$ and $6 A$; but see amplitude $62.1 \pm$ $28.4 \mathrm{pA}$ vs $25.0 \pm 11.3 \mathrm{pA} ; p=0.366)$. One explanation for this discrepancy is very likely to be the distal location of HIPPmediated contacts at postsynaptic apical BC dendrites, which will cause longer delays in action potential conduction in contrast to the proposed proximal contacts among interconnected HIPP cells (Fig. 3B). Consistent with this hypothesis, we observed 

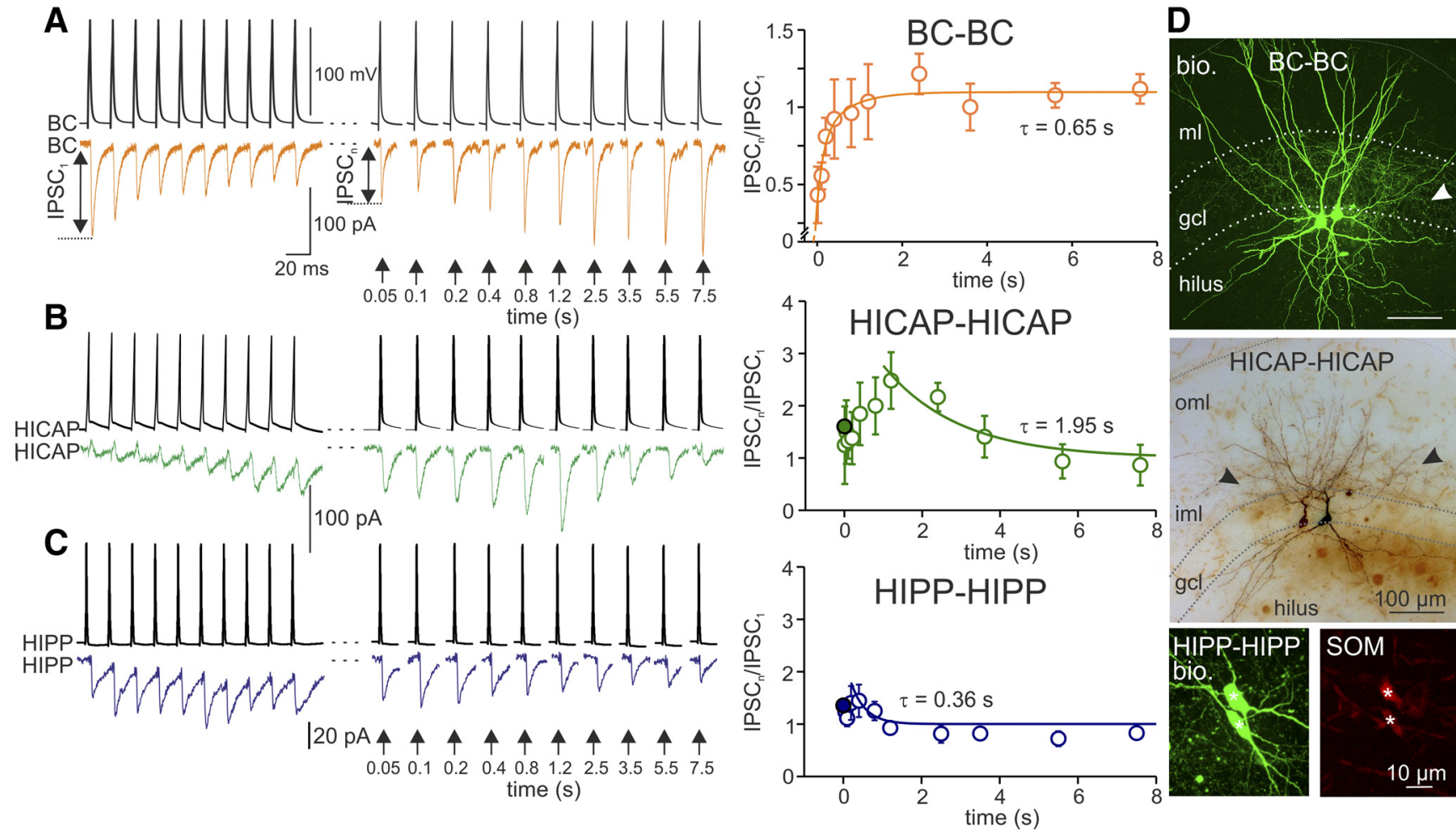

Figure 5. Recovery from multiple-pulse depression at BC-BC and facilitation at HICAP-HICAP and HIPP-HIPP synapses. A-C, A train of 10 action potentials at $50 \mathrm{~Hz}$ (left) was applied to the presynaptic interneuron to evoke multiple-pulse modulation of ulPSCs. Recovery from multiple-pulse modulation was determined by evoking single action potentials in the presynaptic cell with increasing time intervals after the train. Values below arrows indicate length of the time interval after the train (6BC-BC, 7 HICAP-HICAP and 5 HIPP-HIPP pairs). Right, Time course of recovery from multiple-pulse modulation. Amplitude ratio of evoked IPSC after the train and the first IPSC in the train (IPSC $/$ /PSC ${ }_{1}$ ) are plotted against the time interval. Lines represent monoexponential fit to the data with a time constant $(\tau)$ of $0.65 \mathrm{~s}$ for BC-BC synapses ( 6 pairs), $1.95 \mathrm{~s}$ for HICAP-HICAP ( 7 pairs), and $0.36 \mathrm{~s}$ for HIPP-HIPP ( 5 pairs) synapses. Averages from $>10$ single traces are shown. Filled circles represent the mean amplitude of the last uIPSC in the $50 \mathrm{~Hz}$ train. Data points are mean \pm SEM. D, Top, Confocal image stack of a BC $-B C$ pair. Arrowheads indicate location of axon collaterals in the granule cell layer ( $\mathrm{gcl})$. Middle, Micrograph of a DAB-labeled HICAP-HICAP pair. Arrowheads indicate axon collaterals in the inner molecular layer (iml). Bottom, Confocal image stack of an intracellularly labeled HIPP-HIPP pair with biocytin (left) that expresses somatostatin (SOM, right). Stars represent cell bodies. Gray dotted lines indicate borders between the gcl and hilus, the gcl and the iml, and between the outer molecular layer (oml) and hippocampal fissure ( $\mathrm{ml}$, molecular layer).

bouton-like structures of HIPP axons in close apposition to apical $\mathrm{BC}$ dendrites in the middle molecular layer (3 HIPP-BC pairs; Fig. 6B). A distal HIPP-BC synapse location was further supported by comparing the functional properties with HICAP-BC synapses. The mean rise times of their uIPSCs were similarly slow $(0.7 \pm 0.1 \mathrm{~ms}$ vs $0.7 \pm 0.06 \mathrm{~ms}, p=0.765$; Fig. $6 A)$ and 1.8 -fold slower than at BC-BC synaptic responses (Fig. 2A). Thus, deceleration of uIPSCs evoked by distally located synapses may underlie the long latency and slow rise time of dendrite-targeting synapses in BCs.

Similar to the rise time, the mean $\tau$ of inhibitory signals was not significantly different at HICAP-BC and HIPP-BC synapses ( $5.5 \pm 0.3 \mathrm{~ms}$ vs $5.5 \pm 0.6, p=0.540$; Fig. $6 A)$. This finding is in marked contrast to the significantly slower decay time constants of inhibitory signals observed at HIPP-HIPP connections $(11.0 \pm 1.9 \mathrm{~ms}, p=0.041, p=0.023$; Fig. $2 A)$, suggesting that, within the $\mathrm{BC}$ population, target cell type-dependent factors, such as the homogeneous expression profile of $\mathrm{GABA}_{\mathrm{A}}$ receptor subunits, may play a role in defining the fast time course of uIPSCs (Fritschy and Mohler, 1995).

\section{Dynamic properties of inhibitory signals at heterologous interneuron-BC synapses}

To examine whether dynamic changes in GABA release can be observed at interneuron-BC synapses (Fig. 6D), we applied trains of 10 action potentials at $50 \mathrm{~Hz}$ to the presynaptic cell. In contrast to the facilitating inhibitory response in HICAP-HICAP and bi- phasic response in HIPP-HIPP paired recordings (Fig. 4A, B), subsequently evoked uIPSCs at interneuron-BC synapses underwent only mild fluctuations in their amplitude $\left(\mathrm{IPSC}_{10} / \mathrm{IPSC}_{1}\right.$ HICAP-BC: $0.84 \pm$ 0.1, 8 pairs; HIPP-BC: $1.05 \pm 0.4,6$ pairs; Fig. $6 D$ ). We refer to this form of GABA release in the following "constant transmission." These data suggest that short-term dynamics of inhibition are defined not only by presynaptic mechanisms but also by the nature of the target cell. Our data further indicate that repetitive activation of defined interneuron types can provide fine-tuned inhibition, dependent on the cell type. For example, HICAPs provide facilitating inhibition onto target HICAPs, constant transmission onto BCs, but depressing inhibition onto glutamatergic granule cells (GCs; see also Reyes et al., 1998; Hefft and Jonas, 2005). These differential dynamics of synaptic signaling might be caused by alterations in the molecular structure of presynaptic sites induced by retrograde signals from the target neuron.

Dendritic inhibition controls probability and timing of action potential generation

Can the apparently weak, unreliable, and slow dendritic inhibition modulate target cell activity? To address this question, we used an optophysiological approach (Fig. 7) in which we injected a Cre-inducible rAAV vector containing ChR2-tdT into the DG of SOM-Cre mice (see Materials and Methods). Immunohistochemical labeling showed that $30.8 \%$ of $\mathrm{SOM}^{+}$cells expressed ChR2-tdT upon injection (Fig. 7A; 12 slices, two animals), and 


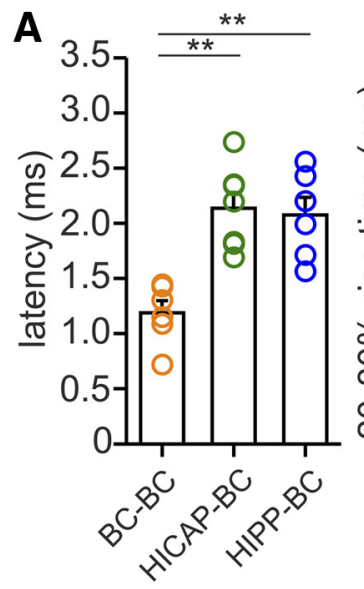

B

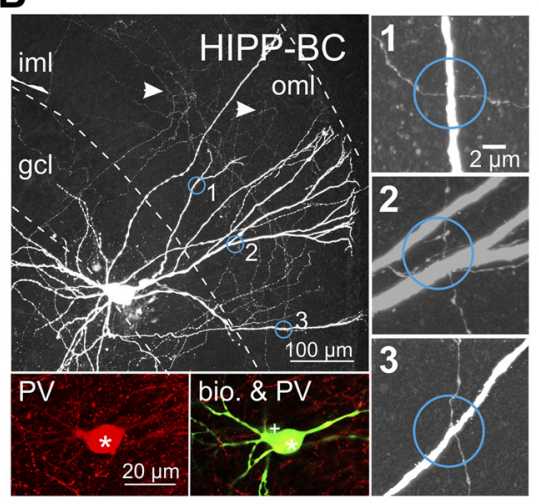

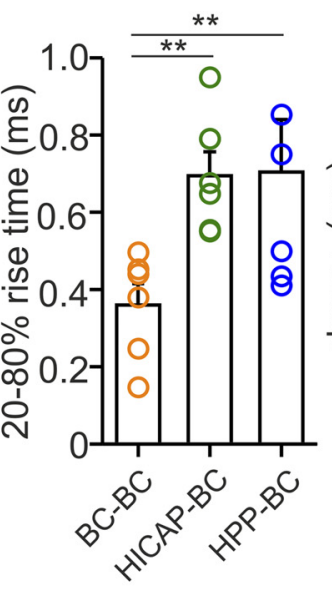

C

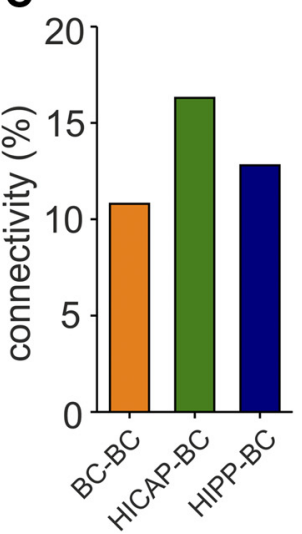

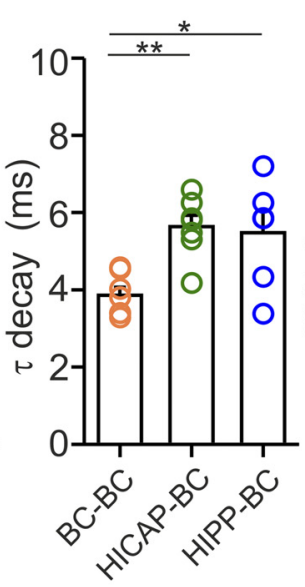

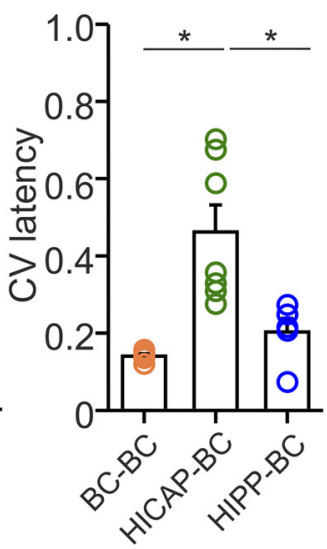

D

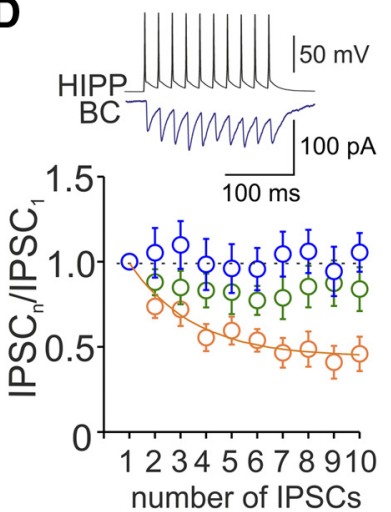

Figure 6. Kinetic and dynamic properties of uIPSCS at heterologous interneuron-BC synapses. $A$, Summary graphs of synaptic latency, $20 \%-80 \%$ rise time, decay time constant $(\tau)$, and $C V$ in synaptic latency of uIPSCs at BC-BC (6 pairs), HICAP-BC (8 pairs), and HIPP-BC (6 pairs) synapses. B, Top, Confocal image stack of a HIPP-BC pair. Arrows indicate axon collaterals in the outer and middle molecular layer (oml). Areas surrounded by blue circles are shown at high magnification on the right. Bottom, Antibody labeling against PV (left); superposition of PV and biocytin (bio) labeling (right). Star represents the BC; + indicates the HIPP soma located behind the PV ${ }^{+}$cell body. Right, Deconvolved image stack of 3 visually identified putative synapses. C, Probability of possible unidirectional connections between interneuron types and postsynaptic BCs (HICAP-BCs, 15 pairs of 92 simultaneous dual HICAP-like and BC-like recordings; HIPP-BCs 12 pairs of 94 simultaneous dual SOM-GFP cell and BC recordings). D, Multiple-pulse dynamics at interneuron-BC synapses. Top, Trains of 10 action potentials were applied at 50 Hz to the presynaptic HIPP cell (top trace), and uIPSCs were recorded at postsynaptic BCs (lower trace; average of 30 single traces). IPSC $C_{n} / I P S C_{1}$ is plotted as a function of the subsequently evoked IPSCs during the train. Note the constant inhibitory signaling at HICAP-BC-like (green circles) and HIPP-BC synapses (blue circles) as well as multiple-pulse depression at BC-BC synapses (orange circles, same data as in Fig. $4 B$, left). Line indicates exponential fit. Error bars indicate mean \pm SEM. $A$, Circles represent single data points. $\boldsymbol{D}$, Circles represent mean \pm SEM. ${ }^{* *} p \leq 0.01$. ${ }^{*} p \leq 0.05$.

95.6\% of ChR2-tdT cells expressed SOM confirming the high selectivity of Cre-expression in SOM-positive cells of the DG. Whole-cell recordings confirmed that application of blue light pulses ( $2 \mathrm{~ms} ; 473 \mathrm{~nm}$ ) reliably evoked single action potentials in ChR2-tdT-expressing SOM ${ }^{+}$cells (16 cells; Fig. 7B). To determine the effect of dendritic inhibition on the recruitment of target neurons, we evoked train of 3 excitatory inputs at $20 \mathrm{~Hz}$ in BCs by extracellular stimulation of the PP (Fig. 7C). Consistent with the facilitating nature of PP-mediated EPSCs, spike probability increased from $0 \%$ in response to the first, to $57.1 \pm 9.9 \%$ at the second, and $76.7 \pm 5.2 \%$ at the third stimulus ( 6 cells). We recruited SOM axons by light pulses applied to the outer molecular layer. Intensity of the light was set to a value that evoked a first population IPSC with a size similar to the mean amplitude determined in SOM cell-BC paired recordings. Recruitment of SOM-axons during simultaneous PP stimulation resulted in a marked reduction in action potential probability for both the first and second spike corresponding to the second and third PP stimulus (first spike: $57.1 \pm 9.9 \%$ vs $11.0 \pm 4.1 \%, p=0.00095$; second spike: $76.7 \pm 5.2 \%$ vs $38.8 \pm 10.6 \%, p=0.001 ; 6$ cells; Fig. $7 C$, right, $D$ ), and a significant delay in the mean spike timing for the first action potential (first spike: $4.0 \pm 0.2 \mathrm{~ms}$ vs $4.3 \pm 0.3 \mathrm{~ms}, p=$
0.028; second spike: $4.5 \pm 0.4$ vs $4.7 \pm 0.4 \mathrm{~ms}, p=0.0614$; Fig. $7 D$, right). Despite the reduced discharge probability, the precision in action potential generation was higher as reflected by the 2 times lower SD of the latency for the first spike $(0.4 \pm 0.03$ vs $0.2 \pm 0.03$, $p=0.07 ; 6$ cells; Fig. $7 D$, right).

The reduced probability and enhanced precision in action potential generation could be explained by a significant change in the amplitude and kinetics of the underlying mean EPSP, respectively. Indeed, the amplitude of the first EPSP diminished from $11.6 \pm 1.6 \mathrm{mV}$ in controls to $8.7 \pm 1.1 \mathrm{mV}$ when PP stimulation was combined with light-evoked inhibition ( $p=0.031$; see Materials and Methods). At the same time, 20\%-80\% EPSP rise time was reduced $(1.2 \pm 0.2 \mathrm{~ms}$ vs $1.1 \pm 0.2 \mathrm{~ms} ; p=0.00081)$ and the half-duration of the EPSP declined 1.2-fold $(8.2 \pm 1.2 \mathrm{~ms}$ vs $6.9 \pm 1.3 \mathrm{~ms} ; 7$ cells; $p=0.032$ ). The observed reduction in size and half-duration of evoked EPSPs will result in a narrower time window for action potential generation and thereby in the reduced spike probability and jitter. Moreover, a reduced $20 \%$ $80 \%$ rise time and peak amplitude will cause the observed decline in the maximal slope of EPSPs (EPSP: $8.9 \pm 1.8 \mathrm{Vms}^{-1}$ in controls vs $7.6 \pm 1.2 \mathrm{Vms}^{-1}$ upon light exposure; $p=0.031$ ), which will result in a longer latency to the action potential threshold and 
the observed delay in the mean spike time (Fig. 7D). The precision in timing of the second spike was not significantly altered (Fig. 7D), which could be explained by the marked paired pulse facilitation of the PPmediated EPSC (Fig. 7C). The observed effects were not caused by presynaptic mechanisms at PP inputs because neither the CV in the mean peak amplitude of the first and second EPSC before and after light induction (first EPSC: $0.31 \pm 0.14 \mathrm{vs}$ $0.19 \pm 0.08, p=0.438$; second EPSC: $0.1 \pm 0.02$ vs $0.1 \pm 0.01, p=0.813$ ) nor the ratio between two subsequently evoked EPSCs was altered $\left(\mathrm{EPSC}_{2} / \mathrm{EPSC}_{1}\right.$ : $1.65 \pm 0.2$ vs $1.76 \pm 0.2, p=0.125$; $\mathrm{EPSC}_{3} / \mathrm{EPSC}_{2}: 1.12 \pm 0.05$ vs $1.12 \pm 0.04$, $p=1.0)$. Thus, dendritic inhibition at SOM cell to BC synapses reduces spike probability but at the same time improves the timing and precision of single action potentials. This effect is, however, dependent on the balance in the strength between synaptic excitation and inhibition.

\section{Discussion}

Here we have determined the functional and dynamic properties of synapses among interneuron types using a combined morphological, immunocytochemical, and electrophysiological approach. We focused on the DG because in vivo studies indicated that network activity in this area is under tight inhibitory control (Nitz and McNaughton, 2004). Moreover, functional and dynamic characteristics of BC-GC (Geiger et al., 1997) and BC-BC synapses (Bartos at al., 2001, 2002; Vida et al., 2006) have been well characterized in this circuitry, but properties of synaptic inhibition of other types of GABAergic cells in particular onto interneurons, remained unknown. We show that CCK-HICAPs and SOM-HIPP cells form layer- and cell-type-specific connectivities. Synaptic connections exist among CCK-HICAP and between SOM-HIPP cells. The two interneuron types rarely inhibit each other but target more often PV-BCs. Inhibition provided by HICAPs and HIPPs is slow, weak, and unreliable compared with BC-mediated fast, strong, and reliable signaling (Kraushaar and Jonas, 2000; Bartos et al., 2007). It can nevertheless effectively control probability and timing of spike generation as revealed by our optophysiological experiments. Finally, we show that strength, time course, and dynamic modulation of inhibitory signals is defined by the identity of presynaptic and postsynaptic interneurons. We propose that this synapse specificity in the properties of inhibitory signaling adds a new level of versatility in information processing in neuronal networks and thereby may enhance their computational power.

\section{Mechanisms defining functional properties of synaptic inhibition among interneurons}

While the primary targets of most interneuron types are principal cells, there is substantial evidence for extensive connectivity between interneurons. Synaptic connections have been found
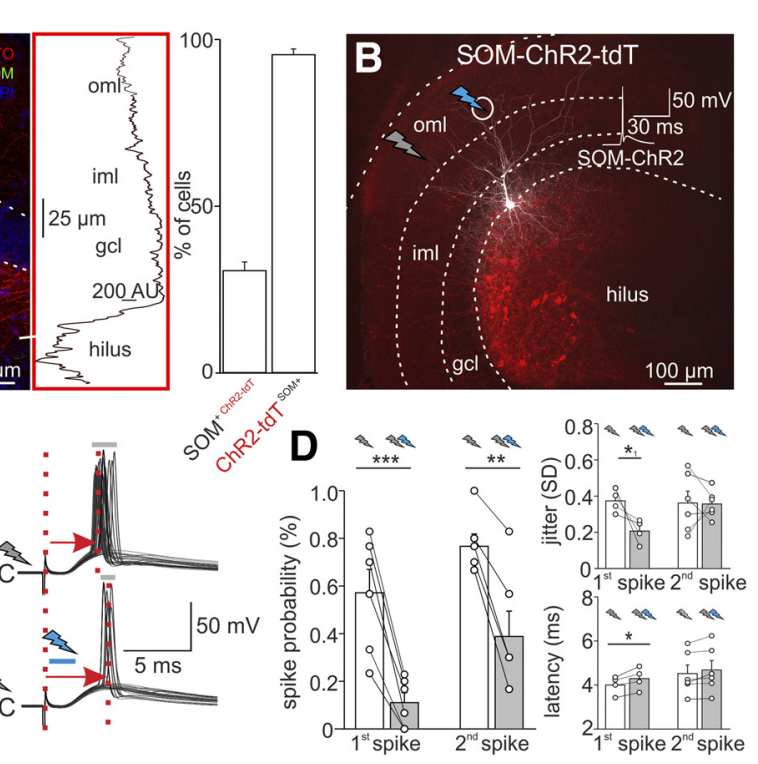

Figure 7. SOM cell-mediated dendritic inhibition reduces frequency and improves precision in action potential generation in target BCs. A, Left, Confocal image stack shows selective expression of ChR2-tdT in SOM-expressing interneurons upon stereotaxic injection of rAAV-ChR2-tdT (Material and Methods). Arrows indicate cell bodies colocalizing ChR2 and SOM. Red square outlines the outer molecular layer (oml). SOM-ChR2-tdT ${ }^{+}$cells were recruited by applying a blue light pulse $(473 \mathrm{~nm}, 2 \mathrm{~ms})$ to the oml. Circle Supermposed aveage EPSC evoked before (black and recorded in the same BC evoked by 3 blue light pulses at 20 Hz. Bottom, action potentials induced by the second PP stimulus during control conditions (upper traces) and in the presence of blue light (lower traces). Gray bars represent the jitter in spike generation. Blue bar represents time of light application. Red dotted lines and red arrows indicate a shift in the mean latency between PP stimulation and spike threshold. $\boldsymbol{D}$, Left, Bar graph represents probalight-induced generation in controls and during SOM-mediated dendritic inhibition. Symbols connected by lines represent single experiments. Error bars indicate mean \pm SEM. ${ }^{* * *} p \leq 0.0001 .{ }^{* *} p \leq 0.01 .{ }^{*} p \leq 0.05 .{ }^{*} 1 p=0.07$.

among PV cells (Cobb et al., 1995; Gulyás et al., 1999; Bartos et al., 2002), CCK interneurons (Mátyás et al., 2004), and neurogliaform cells (Price et al., 2005). Here we show that synaptic inhibition exists among HICAPs and also HIPP cells. These connections suggest that interneuron types are organized into subnetworks acting synergistically in a self-organized manner and thereby support the generation of coherent network oscillations (Wang and Buzsáki, 1996; Bartos et al., 2007). Moreover, we show that there are extensive connections between certain interneuron types, but no or only low connectivity between other types. This selectivity of inhibitory synapses is likely to be important for the entrainment or, alternatively, competitive shifts between the involved subtypes. Connectivity patterns among interneuron types have been recently described in the visual cortex (Pfeffer et al., 2013). In contrast to our findings, PV cells in the visual cortex strongly inhibit one another but avoid other interneuron types, whereas SOM cells avoid inhibiting one another but strongly inhibit other types (Pfeffer et al., 2013). Thus, interneuron connectivity shows brain area-specific patterns.

Interestingly, functional properties of inhibitory synapses among interneurons differed substantially depending on identities of presynaptic and postsynaptic partners. What are 
the possible underlying mechanisms? Our morphological and physiological analysis (Figs. 1, 2, and 3) together with previous experimental and theoretical investigations (Spruston et al., 1994; Häusser and Roth, 1997; Maccaferri et al., 2000; Emri et al., 2001; Nörenberg et al., 2010) suggest that kinetics of inhibitory conductances, synapse number and location as well as dendritic processing jointly determine strength and time course of inhibitory signals at the soma. Attenuation of distally evoked uIPSCs by electrotonic filtering can explain somatically recorded small amplitude uIPSCs at HICAP-HICAP, HIPP-BCs, and HICAP-BCs synapses. Although our light microscopic analysis did not allow precise quantifications of release sites, we propose that their number is lower at HICAP and HIPP than at BC-BC-outputs (Figs. 3 and 6) (Bartos et al., 2001). Dendritic filtering also affects IPSC kinetics. The rise time as the fastest component of uIPSCs will undergo strong deceleration (Häusser and Roth, 1997). Consistently, uIPSCs evoked at distal HIPP-BC synapses had slower rise times than those at BC-BC and HIPP-HIPP synapses (Figs. 2 and 6). Additional factors, such as low precision in timing of uIPSCs (Fig. 2) and asynchronous GABA release at HICAP outputs, may also contribute as shown for output synapses of DG, CA1, and CA3 CCK interneurons (Hefft and Jonas, 2005; Ali and Todorova, 2010; Daw et al., 2010).

The decay of uIPSCs was fastest at BC-BC, followed by HICAP-HICAP and slowest at HIPP-HIPP synapses (Fig. 2). The decay of local inhibitory conductances is mainly shaped by the kinetic properties of $\mathrm{GABA}_{\mathrm{A}}$ receptors $\left(\mathrm{GABA}_{\mathrm{A}} \mathrm{R}\right)$. Indeed, recombinant $\mathrm{GABA}_{\mathrm{A}} \mathrm{Rs}$ composed of $\alpha 1 \beta 2 \gamma 2$ show faster deactivation than those consisting of $\alpha 2 \beta 2 \gamma 2$ (Lavoie et al., 1997). Subunit composition of $\mathrm{GABA}_{\mathrm{A}}$ Rs can vary among interneuron types. The $\alpha 1$ subunit is abundantly expressed in hippocampal and DG PV-BCs (Fritschy and Mohler, 1995; Nusser et al., 1995). Furthermore, electron microscopic studies revealed that $\alpha 1$ is highly localized postsynaptically to PV terminals, in particular if postsynaptic neurons were themselves $\mathrm{PV}^{+}$(Klausberger et al., 2002; Milenkovic et al., 2013). In contrast, $\alpha 2$ is preferentially found in synapses formed by CCK cells (Thomson et al., 2000; Nyíri et al., 2001). Thus, depending on presynaptic and postsynaptic interneuron types, differential expression of $\mathrm{GABA}_{\mathrm{A}} \mathrm{R}$ subunits may contribute to the observed disparities in decay times of uIPSCs.

\section{Mechanisms underlying dynamic characteristics of synaptic inhibtion among interneurons}

Short-term depression and facilitation of GABA release are complex phenomena caused by multiple presynaptic and postsynaptic mechanisms (Schneggenburger et al., 2002). Our CV analysis suggests that the primary locus of short-term modulation is presynaptic. Short-term depression at BC-BC synapses corresponds well to that at BC-GC synapses (Kraushaar and Jonas, 2000; Bartos et al., 2001), suggesting that depression at these two synapses share mechanisms upstream of the exocytotic step (Kraushaar and Jonas, 2000), involving either the inactivation of presynaptic $\mathrm{Ca}^{2+}$ channels (Patil et al., 1998), desensitization of $\mathrm{Ca}^{2+}$ sensors (Thomson and Bannister, 1999), or activation of $\mathrm{GABA}_{\mathrm{B}}$ autoreceptors (Booker et al., 2013). In contrast, depletion of the readily releasable pool (Stevens and Tsujimoto, 1995) is unlikely to contribute because of the ability of $\mathrm{BC}$ outputs to release transmitter at high frequency over prolonged periods (Kraushaar and Jonas, 2000; Bartos et al., 2001).

What are the mechanisms underlying short-term facilitation at HICAP-HICAP synapses? The distance between $\mathrm{Ca}^{2+}$ channels and $\mathrm{Ca}^{2+}$ sensor and the accumulation of free $\mathrm{Ca}^{2+}$ in pre- synaptic terminals have been shown to underlie multiple-pulse facilitation at hippocampal glutamatergic and GABAergic synapses (Yamada and Zucker, 1992; Rozov et al., 2001; Zaitsev et al., 2007). Similar mechanisms may also apply to HICAP-HICAP synapses. Indeed, GABA release at PV-BC and CCK-HICAP outputs depends on distinct voltage-dependent $\mathrm{Ca}^{2+}$ channels. PV-BCs express P/Q-type, whereas CCK interneurons localize $\mathrm{N}$-type channels (Hefft and Jonas, 2005). P/Q-type channels are more effectively coupled to the $\mathrm{Ca}^{2+}$ sensor than N-type channels (Rozov et al., 2001; Hefft and Jonas, 2005), as the latter ones are located more remotely (Wu and Saggau, 1994). Consistent with the proposed difference, we observed low failure rates and high temporal precision at $\mathrm{BC}$ output synapses and high failure rate with low precision in GABA release at HICAP outputs (Figs. 2 and 6). Facilitation can be explained by a low initial coupling and progressive $\mathrm{Ca}^{2+}$ accumulation during a train. Although the identity of $\mathrm{Ca}^{2+}$ channels in HIPP cell terminals is unknown, similar mechanisms could account for the initial facilitation during the biphasic response at HIPP-HIPP synapses (Fig. 4). If increasing release probability is not supported by a substantial readily releasable pool, release will decline resulting in reduced facilitation observed later in the train.

\section{Implications for the functional role of HICAP- and HIPP cells in the dentate gyrus}

The DG shows a laminar structure with layer-specific distribution of afferents, including the PP and CA pathway (Cajal, 1968; Amaral, 1978; Förster et al., 2006; Witter, 2010). Embedded in this structure, interneurons receive, depending on their dendritic distribution, input from divergent combinations of excitatory inputs. BCs and HICAPs receive input from the PP, the CA pathway, and GCs (Sambandan et al., 2010) and mediate feedforward or feedback inhibition. HIPPs in contrast receive mainly GC inputs and contribute to feedback inhibition (Hosp et al., 2013). Thus, during repetitive activity of the $\mathrm{PP}$, such as during $\theta$-modulated $\gamma$ oscillations in vivo (Leutgeb et al., 2007), BCs and HICAPs will be directly recruited and provide rapid perisomatic and proximal dendritic inhibition, respectively, onto GCs and interneurons. HIPPs will be subsequently recruited by activated GCs and provide delayed distal dendritic inhibition. As PV-BCs and CCK-HICAPs do not inhibit SOM-HIPPs (Acsády et al., 2000), HIPP cells can be efficiently recruited to provide powerful inhibition to apical dendrites of GCs and interneurons. The apparent lack of HIPP-HICAP connections further suggests that proximal and distal dendritic inhibition does not compete with but rather complement each other spatially as well as temporally. Thus, microcircuit structure of the DG suggests a shift from perisomatic to distal dendritic signaling during a single PP-mediated excitatory wave. During repetitive activation of the PP (Leutgeb et al., 2007), perisomatic inhibition will rapidly decline but dendritic inhibition will increase, further promoting the inhibitory somatodendritic shift, a process comparable with that observed in CA1 (Pouille and Scanziani, 2004).

In conclusion, the complex connectivity and diversity in functional and dynamic properties of interneuron-interneuron synapses add a new dimension to microcircuit interactions in the DG. These interactions shape the temporal evolution of the spatial distribution of inhibition during afferent activation patterns and thereby enhance the dynamical range of information processing and the computational power of the DG network. 


\section{References}

Acsády L, Katona I, Martinez-Guijarro FJ, Buzsáki G, Freund TF (2000) Unusual target selectivity of perisomatic inhibitory cells in the hilar region of the rat hippocampus. J Neurosci 20:6907-6919. Medline

Ali AB, Todorova M (2010) Asynchronous release of GABA via tonic cannabinoid receptor activation at identified interneuron synapses in rat CA1. Eur J Neurosci 31:1196-1207. CrossRef Medline

Amaral DG (1978) A Golgi study of cell types in the hilar region of the hippocampus in the rat. J Comp Neurol 182:851-914. CrossRef Medline

Andersen P, Bliss TV, Skrede KK (1971) Lamellar organization of hippocampal excitatory pathways. Exp Brain Res 13:222-238. Medline

Bartos M, Elgueta C (2012) Functional characteristics of parvalbumin- and cholecystokinin-expressing basket cells. J Physiol 590:669-681. Medline

Bartos M, Vida I, Frotscher M, Geiger JR, Jonas P (2001) Rapid signaling at inhibitory synapses in a dentate gyrus interneuron network. J Neurosci 21:2687-2698. Medline

Bartos M, Vida I, Frotscher M, Meyer A, Monyer H, Geiger JR, Jonas P (2002) Fast synaptic inhibition promotes synchronized $\gamma$ oscillations in hippocampal interneuron networks. Proc Natl Acad Sci U S A 99:13222_13227. CrossRef Medline

Bartos M, Vida I, Jonas P (2007) Synaptic mechanisms of synchronized $\gamma$ oscillations in inhibitory interneuron networks. Nat Rev Neurosci 8:45-56. CrossRef Medline

Bekkers JM, Delaney AJ (2001) Modulation of excitability by $\alpha$-dendrotoxinsensitive potassium channels in neocortical pyramidal neurons. J Neurosci 21:6553-6560. Medline

Booker SA, Gross A, Althof D, Shigemoto R, Bettler B, Frotscher M, Hearing M, Wickman K, Watanabe M, Kulik Á, Vida I (2013) Differential $\mathrm{GABA}_{\mathrm{B}}$-receptor-mediated effects in perisomatic- and dendrite-targeting parvalbumin interneurons. J Neurosci 33:7961-7974. CrossRef Medline

Bragin A, Jandó G, Nádasdy Z, Hetke J, Wise K, Buzsáki G (1995) Gamma $(40-100 \mathrm{~Hz})$ oscillation in the hippocampus of the behaving rat. J Neurosci 15:47-60. Medline

Buckmaster PS, Schwartzkroin PA (1995) Physiological and morphological heterogeneity of dentate gyrus-hilus interneurons in the gerbil hippocampus in vivo. Eur J Neurosci 7:1393-1402. CrossRef Medline

Buzsáki G, Draguhn A (2004) Neuronal oscillations in cortical networks. Science 304:1926-1929. CrossRef Medline

Cajal SR (1968) The structure of the Ammon's horn. Springfield, IL: Charles C. Thomas.

Chiu CQ, Lur G, Morse TM, Carnevale NT, Ellis-Davies GC, Higley MJ (2013) Compartmentalization of GABAergic inhibition by dendritic spines. Science 340:759-762. CrossRef Medline

Cobb SR, Buhl EH, Halasy K, Paulsen O, Somogyi P (1995) Synchronization of neuronal activity in hippocampus by individual GABAergic interneurons. Nature 378:75-78. CrossRef Medline

Csicsvari J, Jamieson B, Wise KD, Buzsáki G (2003) Mechanisms of $\gamma$ oscillations in the hippocampus of the behaving rat. Neuron 37:311-322. CrossRef Medline

Daw MI, Pelkey KA, Chittajallu R, McBain CJ (2010) Presynaptic kainate receptor activation preserves asynchronous GABA release despite the reduction in synchronous release from hippocampal cholecystokinin interneurons. J Neurosci 30:11202-11209. CrossRef Medline

Dinkel A, Aicher WK, Warnatz K, Bürki K, Eibel H, Ledermann B (1999) Efficient generation of transgenic $\mathrm{BALB} / \mathrm{c}$ mice using $\mathrm{BALB} / \mathrm{c}$ embryonic stem cells. J Immunol Methods 223:255-260. CrossRef Medline

Doischer D, Hosp JA, Yanagawa Y, Obata K, Jonas P, Vida I, Bartos M (2008) Postnatal differentiation of basket cells from slow to fast signaling devices. J Neurosci 28:12956-12968. CrossRef Medline

Emri Z, Antal K, Gulyás AI, Megías M, Freund TF (2001) Electrotonic profile and passive propagation of synaptic potentials in three subpopulations of hippocampal CA1 interneurons. Neuroscience 104:1013-1026. CrossRef Medline

Förster E, Zhao S, Frotscher M (2006) Laminating the hippocampus. Nat Rev Neurosci 7:259-267. CrossRef Medline

Freund TF, Buzsáki G (1996) Interneurons of the hippocampus. Hippocampus 6:347-470. Medline

Fritschy JM, Mohler H (1995) $\mathrm{GABA}_{\mathrm{A}}$-receptor heterogeneity in the adult rat brain: differential regional and cellular distribution of seven major subunits. J Comp Neurol 359:154-194. CrossRef Medline

Geiger JR, Lübke J, Roth A, Frotscher M, Jonas P (1997) Submillisecond AMPA receptor-mediated signaling at a principal neuron-interneuron synapse. Neuron 18:1009-1023. CrossRef Medline

Glickfeld LL, Scanziani M (2006) Distinct timing in the activity of cannabinoid-sensitive and cannabinoid-insensitive basket cells. Nat Neurosci 9:807-815. CrossRef Medline

Gulyás AI, Megías M, Emri Z, Freund TF (1999) Total number and ratio of excitatory and inhibitory synapses converging onto single interneurons of different types in the CA1 area of the rat hippocampus. J Neurosci 19: 10082-10097. Medline

Halasy K, Somogyi P (1993) Subdivisions in the multiple GABAergic innervation of granule cells in the dentate gyrus of the rat hippocampus. Eur J Neurosci 5:411-429. CrossRef Medline

Han ZS, Buhl EH, Lörinczi Z, Somogyi P (1993) A high degree of spatial selectivity in the axonal and dendritic domains of physiologically identified local circuit-neurons in the dentate gyrus of the rat hippocampus. Eur J Neurosci 5:395-410. CrossRef Medline

Hartwich K, Pollak T, Klausberger T (2009) Distinct firing patterns of identified basket and dendrite-targeting interneurons in the prefrontal cortex during hippocampal theta and local spindle oscillations. J Neurosci 29: 9563-9574. CrossRef Medline

Häusser M, Roth A (1997) Estimating the time course of the excitatory synaptic conductance in neocortical pyramidal cells using a novel voltage jump method. J Neurosci 17:7606-7625. Medline

Hefft S, Jonas P (2005) Asynchronous GABA release generates long-lasting inhibition at a hippocampal interneuron-principal neuron synapse. Nat Neurosci 8:1319-1328. CrossRef Medline

Hosp JA, Strüber M, Yanagawa Y, Obata K, Vida I, Jonas P, Bartos M (2013) Morpho-physiological criteria divide dentate gyrus interneurons into classes. Hippocampus 24:189-203. CrossRef Medline

Hu H, Martina M, Jonas P (2010) Dendritic mechanisms underlying rapid synaptic activation of fast-spiking hippocampal interneurons. Science 327:52-58. CrossRef Medline

Isaacson JS, Scanziani M (2011) How inhibition shapes cortical activity. Neuron 72:231-243. CrossRef Medline

Jones MV, Westbrook GL (1996) The impact of receptor desensitization on fast synaptic transmission. Trends Neurosci 19:96-101. CrossRef Medline

Klausberger T, Somogyi P (2008) Neuronal diversity and temporal dynamics: the unity of hippocampal circuit operations. Science 321:53-57. CrossRef Medline

Klausberger T, Roberts JD, Somogyi P (2002) Cell type- and input-specific differences in the number and subtypes of synaptic $\mathrm{GABA}_{\mathrm{A}}$ receptors in the hippocampus. J Neurosci 22:2513-2521. Medline

Kraushaar U, Jonas P (2000) Efficacy and stability of quantal GABA release at a hippocampal interneuron-principal neuron synapse. J Neurosci 20: 5594-5607. Medline

Lavoie AM, Tingey JJ, Harrison NL, Pritchett DB, Twyman RE (1997) Activation and deactivation rates of recombinant $\mathrm{GABA}_{\mathrm{A}}$ receptor channels are dependent on $\alpha$-subunit isoform. Biophys J 73:2518-2526. CrossRef Medline

Leão RN, Mikulovic S, Leão KE, Munguba H, Gezelius H, Enjin A, Patra K, Eriksson A, Loew LM, Tort AB, Kullander K (2012) OLM interneurons differentially modulate $\mathrm{CA} 3$ and entorhinal inputs to hippocampal CA1 neurons. Nat Neurosci 15:1524-1530. CrossRef Medline

Leranth C, Frotscher M (1986) Synaptic connections of cholecystokinin immunoreactive neurons and terminals in the rat fascia dentate: a combined light and electron microscopic study. J Comp Neurol 254:51-64. CrossRef Medline

Leutgeb JK, Leutgeb S, Moser MB, Moser EI (2007) Pattern separation in the dentate gyrus and CA3 of the hippocampus. Science 315:961-966. CrossRef Medline

Longair MH, Baker DA, Armstrong JD (2011) Simple neurite tracer: open source software for reconstruction, visualization and analysis of neuronal processes. Bioinformatics App Notes 27:2453-2454. CrossRef Medline

Ma WP, Liu BH, Li YT, Huang ZJ, Zhang LI, Tao HW (2010) Visual representations by cortical somatostatin inhibitory neurons: selective but with weak and delayed responses. J Neurosci 30:14371-14379. CrossRef Medline

Ma Y, Hu H, Agmon A (2012) Short-term plasticity of unitary inhibitoryto-inhibitory synapses depends on the presynaptic interneuron subtype. J Neurosci 32:983-988. CrossRef Medline

Maccaferri G, Roberts JD, Szucs P, Cottingham CA, Somogyi P (2000) Cell surface domain specific postsynaptic currents evoked by identified GABAergic neurones in rat hippocampus in vitro. J Physiol 524:91-116. CrossRef Medline

Malinow R, Tsien RW (1990) Presynaptic enhancement shown by wholecell recordings of long-term potentiation in hippocampal slices. Nature 346:177-180. CrossRef Medline

Mátyás F, Freund TF, Gulyás AI (2004) Convergence of excitatory and inhibitory inputs onto CCK-containing basket cells in the CAl area of the rat hippocampus. Eur J Neurosci 19:1243-1256. CrossRef Medline 
McBain CJ, Fisahn A (2001) Interneurons unbound. Nat Rev Neurosci 2:11-23. CrossRef Medline

McHugh TJ, Jones MW, Quinn JJ, Balthasar N, Coppari R, Elmquist JK, Lowell BB, Fanselow MS, Wilson MA, Tonegawa S (2007) Dentate gyrus NMDA receptors mediate rapid pattern separation in the hippocampal network. Science 317:94-99. CrossRef Medline

Megías M, Emri Z, Freund TF, Gulyás AI (2001) Total number and distribution of inhibitory and excitatory synapses on hippocampal CA1 pyramidal cells. Neuroscience 102:527-540. CrossRef Medline

Milenkovic I, Vasiljevic M, Maurer D, Höger H, Klausberger T, Sieghart W (2013) The parvalbumin-positive interneurons in the mouse dentate gyrus express GABA(A)receptor subunits $\alpha 1, \beta 2$, and $\delta$ along their extrasynaptic cell membrane. Neuroscience 254:80-96. CrossRef Medline

Miles R, Tóth K, Gulyás AI, Hájos N, Freund TF (1996) Differences between somatic and dendritic inhibition in the hippocampus. Neuron 16:815823. CrossRef Medline

Mott DD, Turner DA, Okazaki MM, Lewis DV (1997) Interneurons of the dentate-hilus border of the rat dentate gyrus: morphological and electrophysiological heterogeneity. J Neurosci 17:3990-4005. Medline

Murray AJ, Sauer JF, McClure C, Ansel L, Cheyne L, Riedel G, Bartos M, Wisden W, Wulff P (2011) Parvalbumin-positive hippocampal interneurons are required for spatial working but not reference memory. Nat Neurosci 14:297-299. CrossRef Medline

Nitz D, McNaughton B (2004) Differential modulation of CA1 and dentate gyrus interneurons during exploration of novel environments. J Neurophysiol 91:863-872. CrossRef Medline

Nörenberg A, Hu H, Vida I, Bartos M, Jonas P (2010) Distinct non-uniform cable properties optimize rapid signaling in fast-spiking GABAergic interneurons. Proc Natl Acad Sci U S A 117:894-899. CrossRef Medline

Nusser Z, Roberts JD, Baude A, Richards JG, Sieghart W, Somogyi P (1995) Immunocytochemical localization of the $\alpha 1$ and $\beta 2 / 3$ subunits of the $\mathrm{GABA}_{\mathrm{A}}$ receptor in relation to specific GABAergic synapses in the dentate gyrus. Eur J Neurosci 7:630-646. CrossRef Medline

Nyíri G, Freund TF, Somogyi P (2001) Input-dependent synaptic targeting of $\alpha 2$ subunit containing $\mathrm{GABA}_{\mathrm{A}}$ receptors in synapses in hippocampal pyramidal cells of the rat. Eur J Neurosci 13:428-442. CrossRef Medline

Oliva AA Jr, Jiang M, Lam T, Smith KL, Swann JW (2000) Novel hippocampal interneuronal subtypes identified using transgenic mice that express green fluorescent protein in GABAergic interneurons. J Neurosci 20: 3354-3368. Medline

Patil PG, Brody DL, Yue DT (1998) Preferential closed-state inactivation of neuronal calcium channels. Neuron 20:1027-1038. CrossRef Medline

Pfeffer CK, Xue M, He M, Huang ZJ, Scanziani M (2013) Inhibition of inhibition in visual cortex: the logic of connections between molecularly distinct interneurons. Nat Neurosci 16:1068-1076. CrossRef Medline

Pouille F, Scanziani M (2001) Enforcement of temporal fidelity in pyramidal cells by somatic feed-forward inhibition. Science 293:1159-1163. CrossRef Medline

Pouille F, Scanziani M (2004) Routing of spike series by dynamic circuits in the hippocampus. Nature 429:717-723. CrossRef Medline

Price CJ, Cauli B, Kovacs ER, Kulik A, Lambolez B, Shigemoto R, Capogna M (2005) Neurogliaform neurons form a novel inhibitory network in the hippocampal CA1 area. J Neurosci 25:6775-6786. CrossRef Medline

Reyes A, Lujan R, Rozov A, Burnashev N, Somogyi P, Sakmann B (1998) Target-cell-specific facilitation and depression in neocortical circuits. Nat Neurosci 1:279-285. CrossRef Medline

Rozov A, Burnashev N, Sakmann B, Neher E (2001) Transmitter release modulation by intracellular $\mathrm{Ca}^{2+}$ buffers in facilitating and depressing nerve terminals of pyramidal cells in layer $2 / 3$ of the rat neocortex indicates a target cell-specific difference in presynaptic calcium dynamics. J Physiol 531:807-826. CrossRef Medline

Rudy B, McBain CJ (2001) Kv3 channels: voltage-gated $\mathrm{K}^{+}$channels designed for high-frequency repetitive firing. Trends Neurosci 24:517-526. CrossRef Medline

Sambandan S, Sauer JF, Vida I, Bartos M (2010) Associative plasticity at excitatory synapses facilitates recruitment of fast-spiking interneurons in the dentate gyrus. J Neurosci 30:11826-11837. CrossRef Medline

Sauer JF, Bartos M (2010) Recruitment of early postnatal parvalbuminpositive hippocampal interneurons by GABAergic excitation. J Neurosci 30:110-115. CrossRef Medline

Schneggenburger R, Sakaba T, Neher E (2002) Vesicle pools and short-term synaptic depression: lessons from a large synapse. Trends Neurosci 25: 206-212. CrossRef Medline

Somogyi P, Klausberger T (2005) Defined types of cortical interneurons structure space and spike timing in the hippocampus. J Physiol 562:9-26. CrossRef Medline

Spruston N, Jaffe DB, Johnston D (1994) Dendritic attenuation of synaptic potentials and currents: the role of passive membrane properties. Trends Neurosci 17:161-166. CrossRef Medline

Stevens CF, Tsujimoto T (1995) Estimates for the pool size of releasable quanta at a single central synapse and for the time required to refill the pool. Proc Natl Acad Sci U S A 92:846-849. CrossRef Medline

Thomson AM, Bannister AP (1999) Release-independent depression at pyramidal inputs onto specific cell targets: dual recordings in slices of rat cortex. J Physiol 519:57-70. CrossRef Medline

Thomson AM, Bannister AP, Hughes DI, Pawelzik H (2000) Differential sensitivity to Zolpidem of IPSPs activated by morphologically identified CA1 interneurons in slices of rat hippocampus. Eur J Neurosci 12:425436. CrossRef Medline

Treves A, Rolls ET (1994) Computational analysis of the role of the hippocampus in memory. Hippocampus 4:374-391. CrossRef Medline

Tukker JJ, Fuentealba P, Hartwich K, Somogyi P, Klausberger T (2007) Cell type-specific tuning of hippocampal interneuron firing during $\gamma$ oscillations in vivo. J Neurosci 27:8184-8189. CrossRef Medline

Vida I, Bartos M, Jonas P (2006) Shunting inhibition improves robustness of $\gamma$ oscillations in hippocampal interneuron networks by homogenizing firing rates. Neuron 49:107-117. CrossRef Medline

Wang XJ, Buzsáki G (1996) Gamma oscillation by synaptic inhibition in a hippocampal interneuronal network model. J Neurosci 16:6402-6413. Medline

Witter MP (2010) Connectivity of the hippocampus. In: Hippocampal microcircuits: a computational modeler's resource book (Cutsuridis V, Graham B, Cobb S, Vida I, eds), pp 5-26. New York: Springer.

Wu LG, Saggau P (1994) Block of multiple presynaptic calcium channel types by $\omega$-conotoxin-MVIIC at hippocampal CA3 to CA1 synapses. J Neurophysiol 73:1965-1972. Medline

Xu H, Jeong HY, Tremblay R, Rudy B (2013) Neocortical somatostatinexpressing GABAergic interneurons disinhibit the thalamorecipient layer 4. Neuron 77:155-167. CrossRef Medline

Yamada WM, Zucker RS (1992) Time course of transmitter release calculated from simulations of a calcium diffusion model. Biophys J 61:671682. CrossRef Medline

Zaitsev AV, Povysheva NV, Lewis DA, Krimer LS (2007) P/Q-type, but not $\mathrm{N}$-type, calcium channels mediate GABA release from fast-spiking interneurons to pyramidal cells in rat prefrontal cortex. J Neurophysiol 97:3567-3573. CrossRef Medline 